\title{
WOMEN'S LEADERSHIP AND CORPORATE PERFORMANCE
}

Meijun Qian

NO. 472

January 2016
ADB ECONOMICS WORKING PAPER SERIES 
ADB Economics Working Paper Series

\section{Women's Leadership and Corporate Performance}

Meijun Qian

No. 472 | January 2016
Meijun Qian (Meijun.Qian@anu.edu.au) is Associate Professor at the Research School of Finance, Actuarial Studies \& Statistics, Australian National University.

This study was developed based on a background paper for the Asian Development Outlook 2015 Update on

Enabling Women, Energizing Asia. 
Asian Development Bank

6 ADB Avenue, Mandaluyong City

1550 Metro Manila, Philippines

www.adb.org

(C) 2016 by Asian Development Bank

January 2016

ISSN 2313-6537 (Print), 2313-6545 (e-ISSN)

Publication Stock No. WPS167856-2

The views expressed in this paper are those of the author and do not necessarily reflect the views and policies of the Asian Development Bank (ADB) or its Board of Governors or the governments they represent.

ADB does not guarantee the accuracy of the data included in this publication and accepts no responsibility for any consequence of their use.

By making any designation of or reference to a particular territory or geographic area, or by using the term "country" in this document, $A D B$ does not intend to make any judgments as to the legal or other status of any territory or area.

Notes:

1. In this publication, “\$” refers to US dollars.

2. ADB recognizes "Hong Kong" as Hong Kong, China.

The ADB Economics Working Paper Series is a forum for stimulating discussion and eliciting feedback on ongoing and recently completed research and policy studies undertaken by the Asian Development Bank (ADB) staff, consultants, or resource persons. The series deals with key economic and development problems, particularly those facing the Asia and Pacific region; as well as conceptual, analytical, or methodological issues relating to project/program economic analysis, and statistical data and measurement. The series aims to enhance the knowledge on Asia's development and policy challenges; strengthen analytical rigor and quality of ADB's country partnership strategies, and its subregional and country operations; and improve the quality and availability of statistical data and development indicators for monitoring development effectiveness.

The ADB Economics Working Paper Series is a quick-disseminating, informal publication whose titles could subsequently be revised for publication as articles in professional journals or chapters in books. The series is maintained by the Economic Research and Regional Cooperation Department. 


\section{CONTENTS}

TABLES AND FIGURES

ABSTRACT $v$ v

$\begin{array}{ll}\text { I. INTRODUCTION } & 1\end{array}$

II. $\quad$ CONCEPTS, LITERATURE, AND HYPOTHESES 2

A. Conceptual Questions 2

B. Gender Diversity around the World 3

C. Literature 4

D. Asian Countries' Recognition of Gender Diversity Compared

III. DATA AND METHODOLOGY 10

A. The Data 10

B. Empirical Methods $\quad 11$

IV. $\quad$ EMPIRICAL RESULTS ON GENDER DIVERSITY 13

A. Female Representation 13

B. Female Leadership in Corporations $\quad 15$

V. GENDER DIVERSITY AND FIRM PERFORMANCE 17

A. $\quad$ Gender Diversity and Performance-Univariate Comparison 17

B. Board Member Appointment and Firm Performance 20

C. Controlling for Firm and Industry Characteristics 22

VI. ADDRESSING THE SELECTION AND REVERSE CAUSALITY ISSUES 23

$\begin{array}{ll}\text { VII. CONCLUSIONS } & 27\end{array}$

$\begin{array}{lr}\text { REFERENCES } & 29\end{array}$ 


\section{TABLES AND FIGURES}

\section{TABLES}

$1 \quad$ Female Representation in Boardrooms and Senior Management Globally 4

$2 \quad$ Gender Diversity and Financial Performance-Full Sample 23

3 Gender Diversity and Stock Market Returns-by Individual Economy 23

$4 \quad$ Gender Diversity and Firm Performance: Two-Stage Analyses with the 10-Country 4-Year Panel Data $\quad 25$

$5 \quad$ Gender Diversity and Firm Performance: Two-Stage Analyses with the 7-Year Panel Data from Singapore

\section{FIGURES}

$1 \quad$ Industry Distribution of the Sample Firms 11

2 Female Representation on Boards in Asia and the Pacific 13

3 All-Male Boards in Asia and the Pacific 14

$4 \quad$ Proportion of Female Directors, 2013

$5 \quad$ Female Representation by Industry 15

6 Female Board Leadership 16

7 Female Representation among Different Types of Directors 16

8a Female Board Membership and Return on Assets 17

8b Female Board Membership and Return on Equity 18

8c Female Board Membership and Stock Market Returns 18

9a Female Representation on the Board and Return on Assets -Stepwise and by Industry 19

9b Female Representation on the Board and Return on Equity

9c Female Representation on the Board and Stock Market Returns-Stepwise and by Industry 20

$10 \quad$ Female Director Appointment and Departure and Firm Performance 21

11 Male Director Turnover and Firm Performance 21

12 The Stepwise Effect of Adding Female Directors 22 


\begin{abstract}
This paper examines the gender diversity in corporate boardrooms in Asia and the Pacific and how the diversity affects corporate performance. We find that boardroom gender diversity is low in Asia with $7.5 \%$ female representation on average in 2012, but showing a 1.8\% improvement in 2013 . The appointment of female directors and a gender-diverse boardroom are on average positively associated with a firm's subsequent performance, but with large cross-country and cross-measurement differences. Firm performance is the highest when there are two females on the board. Using twostage analyses, we find that (i) a firm's past performance does not predict its choice to add female directors; (ii) cross-country differences in female corporate leadership respond to its economic demand and supply as measured by gender equality in college education, labor participation, wages, and infant survival; and (iii) female representation on the board, when determined by these economic factors, is a significant predictor of a firm's future performance.
\end{abstract}

Keywords: corporate performance, development equality, director choices, female leadership

JEL codes: $\mathrm{G} 38, \mathrm{~J} 71, \mathrm{O} 16$ 


\section{INTRODUCTION}

Gender diversity in corporate leadership concerns efficient allocation of human talents as an economic resource. This issue has increasingly attracted the attention of academics and regulatory institutions in recent years. Many governments explicitly urge corporations to increase female representation in boardrooms and senior management positions. For example, the United Kingdom (UK) proposes a minimum of $25 \%$, Norway mandates $40 \%$, and Germany mandates 30\% female representation in boardrooms. These legislative initiatives are based on the view that tapping female talent pools could positively affect corporate governance and performance. Academic studies using European and United States (US) data, however, could not arrive at a definite conclusion. For example, while Carter, Simkins, and Simpson (2003) show a positive relation between gender diversity and corporate performance, Adams and Ferreira (2009) find a negative effect.

Asian countries have been relatively less proactive in pressuring gender diversity compared with European countries. Research results based on European empirical data are not necessarily applicable to Asian countries because of differences in cultures, demographics, and economic development. As such, studies based on Asian data could inform more effective policies and provide more practical guidance for Asian corporations and economies than references based on foreign experiences.

This paper examines gender diversity practice and its impact on corporate performance in Asia, and in particular, assesses the magnitude of the effects and peculiarities that pertain to developing Asia. To achieve these goals, we first provide a comprehensive description of gender diversity of corporate boardrooms in 10 economies in Asia and the Pacific. Second, we conduct econometric analyses to assess whether gender diversity impacts firm performance and through which channels gender diversity affects firms' performance, e.g., productivity, operational profitability, or market evaluation. Finally, we explore the cross-country differences of gender diversity in Asian boardrooms.

Aside from comprehensiveness, we also stress rigorousness in the empirical methodology used in conducting the analysis. Specifically, as empirical correlations based on the cross-sectional inferences are likely to suffer from the omitted-variable and reverse-causality problems-e.g., whether it is the firm's past performance determining the decision of hiring women, or the decision of hiring women affecting future firm performance, or whether both performance and diversity are determined by other unobserved variables-we will employ a two-stage econometric method and an instrumentvariable approach to address these issues. The international coverage of the data allows for comparisons across countries and industries and exploration of how labor market conditions and economic development may affect the gender diversity practice and its impact on corporations.

We find that boardroom gender diversity is lower in Asia and the Pacific compared with North America and Europe. Australia has the highest diversity in the region and the Republic of Korea the lowest. The People's Republic of China (PRC) has the least public emphasis on gender diversity, but its female representation in boardrooms has grown the fastest. India and Malaysia are the only countries that impose mandatory quotas for gender diversity. The implementation, however, is a different issue. We also find that firms that have at least one female on the board significantly outperform other firms. Appointment of a female director is also positively associated with firms' return on assets (ROA) and return on equity (ROE) in the subsequent year. There is, however, no predictive power between gender diversity and financial performance after we control for endogeneity issues in the analysis. Moreover, the cross-country differences in gender diversity are related to the economic demand and 
supply of female leaders measured by gender equality in education, labor participation, wages, and infant survival. Overall, this study supports the notion that females are underrepresented in corporate leadership. The lack of gender diversity, however, does not necessarily result from inefficient or discriminatory corporate hiring decisions but rather from the premarket conditions for gender equality in the society.

Gender diversity is an important topic for economic and social development. We believe that a comprehensive and thorough study like this one, with discoveries in the aforementioned dimensions of gender diversity in boardrooms in Asia and the Pacific, will make a valuable contribution in understanding and improving the economic well-being of people in the region.

In particular, our study suggests that the selection of corporate leaders is influenced by economic factors and displays large cross-country differences. A mandatory quota, therefore, is not equivalent to an efficient method of allocating human talents. Government policies promoting gender diversity in corporate leadership may focus on promoting the social conditions for gender equality. Equality in talent fostering could be a Pareto improvement in developing human capital, which in turn contributes to economic growth.

The rest of the report is organized as follows. In section II, we review the existing literature on the theories, practices, and performance implications of gender diversity in boardrooms. We also describe in this section the recent recognition of the importance of gender diversity by corporations, academics, and government policies in Asia and the Pacific. Section III details the data and methodologies used in the empirical analyses. Section IV describes the gender diversity status in Asian boardrooms. Section $\vee$ presents the empirical association between boardroom gender diversity and firm performance. Section VI investigates the causal relations between gender diversity and financial performance and explores the cross-country differences in gender diversity. Section VII concludes the report.

\section{CONCEPTS, LITERATURE, AND HYPOTHESES}

\section{A. Conceptual Questions}

Boardroom gender diversity refers to the balance of gender composition of corporate boards. Males have conventionally dominated corporate leadership. Despite the improvements in female education and labor participation, and governments' social efforts to promote gender balance in recent decades, females are still underrepresented in the boardrooms of most countries compared with population composition in general or in specific areas such as higher education, the labor force, and corporate management.

Not only do gender-imbalanced boardrooms violate social equality, gender balance in corporate leadership is important for allocating human talents and hence efficiency in decision making by leaders. Such a balance becomes particularly important if men and women on average substantially differ in their skill sets, social preferences, risk appetites, or value systems. As the leaders control resources and make investment decisions that set the path for the future, gender imbalance in corporate leadership can not only cause an inefficient allocation of current resources, it is also likely to perpetuate the inefficiency and distort the future business world. 
Examining the relation between female leadership and corporate performance sheds light on these important issues. Based on Becker's discrimination theory, firms that discriminate based on nontalent-related factors in their hiring decisions will underperform. Therefore, by examining the relation between gender diversity and firm performance, we can infer the allocative efficiency of human talents without assuming the existence of prejudice.

To do so, this study attempts to answer the following questions: First, is the gender ratio imbalanced in corporate leadership? Second, what are the causes of this imbalance? Third, are there skill and preference differences between men and women and what are the economic implications of these differences in decision making? Finally, what are the inefficiencies associated with gender imbalance and how does gender diversity affect firms' economic performance? To answer these questions, we first provide an overview of gender diversity statistics around the world. We review the literature to summarize what academia and industry have already learned about the gender diversity situation, and identify the remaining questions and their implications. Finally, we empirically investigate the status of gender diversity and its relation to corporate performance in Asia.

\section{B. Gender Diversity around the World}

Two measures are generally used to examine the proportionality of women on corporate boards: (i) the percentage of companies that have at least one woman on their board, and (ii) the percentage of corporate board seats held by women. For female representation in senior management positions, the percentage of senior management positions held by women is often used. In the analysis relating to financial performance, we also use an indicator for the appointment of one or more female directors to measure the change in gender diversity.

The North American and European firms on average do better in both measurements of board gender diversity compared with firms in Asia and the rest of the world. Searching various sources and reports, we find that in 2012, $90 \%$ of the US Standard \& Poor's 500 companies had at least one woman on their board. In 2011, 60\% of the FP500 Canadian companies had at least one woman on their board. In the UK, 79\% of the FTSE100 companies had at least one woman on their board in 2011, and that ratio had risen to $93 \%$ by 2014 . The percentage of European companies with at least one woman on their board was $86 \%$ in 2012. For the Scandinavian countries, there is at least one woman director on every board. In Greece, Italy, and the Netherlands, however, almost a third of all corporate boards are currently still $100 \%$ male.

Based on the 2013 data reported in Dieleman, Qian, and Ibrahim (2014), the percentage of female representation in the board of directors is high in North America but low in Asia. As Table 1 shows, $40.5 \%$ of board seats in Norway are taken by females, $20.7 \%$ in the UK, and $16.9 \%$ in the US. In Asia, the country with the highest ratio is Indonesia (11.6\%), Singapore is in the middle (8.3\%), and the lowest is the Republic of Korea (1.9\%).

The percentage of females in senior management, however, displays an almost opposite geographic pattern, based on the report Women in Business: From Classroom to Boardroom, 2014 by Grant Thornton International. As Table 1 shows, while most of the European firms show less than 20\% female representation in corporate senior management, the ratio is above $40 \%$ for many Asian countries. 
Table 1: Female Representation in Boardrooms and Senior Management Globally

\begin{tabular}{lclc}
\hline Female Representation in Boardrooms & & \multicolumn{2}{l}{ Female Representation in Senior Management } \\
\hline Economy/Region & $(\%)$ & Economy/Region & $(\%)$ \\
\hline Western & & & 22 \\
\hline United States & 16.9 & United States & 20 \\
United Kingdom & 20.7 & United Kingdom & 14 \\
European Union & 16.6 & Denmark & 14 \\
Finland & 26.8 & Germany & 10 \\
Norway & 40.5 & Holland & 13 \\
Sweden & 27.0 & Switzerland & 33 \\
\hline Asia/ Pacific/Mideast & & & 14 \\
\hline People's Republic of China & 8.5 & Thailand & 40 \\
India & 5.2 & India & \\
Republic of Korea & 1.9 & Philippines & \\
Malaysia & 8.6 & & 9 \\
Singapore & 8.3 & & 35 \\
Japan & 2.0 & Japan & 35 \\
Hong Kong, China & 9.6 & & \\
Indonesia & 11.6 & Indonesia & \\
Australia & 18.2 & Armenia & \\
New Zealand & 14.8 & Georgia & \\
\hline
\end{tabular}

Sources: Marleen Dieleman, Meijun Qian, and Muhammad Ibrahim. 2014. Singapore Board Diversity Report 2014-Picture the Performance Premium. Centre for Governance, Institutions and Organisations; and Grant Thornton International. 2014. Women in Business: From Classroom to Boardroom, Grant Thornton International Business Report 2014.

\section{Literature}

We comprehensively review the theories and empirical works. Our review does not assume gender equality or inequality, but tries to learn what explains the cross-sectional differences in diversity, why a gap exists between men's and women's presence at the top of the corporate ladder, whether and why the gap matters for financial performance, and what is the effect of government mandatory policies on gender diversity in corporate leadership.

\section{Explanations of Gender Diversity Status}

Farell and Hersch (2005), based on the US Fortune 500 firm data from 1990 to 2000, show that adding a director is gender neutral. The likelihood of a firm adding a woman to its board in a given year is negatively associated with the number of women already on the board and positively associated with the departure of another. Adams and Kirchmaier (2013) examine gender diversity and its relation to female labor participation in 22 countries over the period 2001-2010. They find that labor force participation and the presence of boardroom quotas are significantly related to the representation of women on boards. Economic and cultural factors may be important barriers to female career advancement, but preferences may be less important. They suggest that while quotas may overcome 
problems of discrimination, they may be too narrow a policy tool to address other causes of low female representation in corporate leadership.

Grant Thornton International (2015), drawing on 5,404 interviews in 35 economies and 20 indepth interviews with senior business leaders, reports that women's advancement is being constrained by a number of factors, from entrenched social norms and gender bias to parenthood and archaic business practices. The report also recommends measures to improve the advancement of women in corporate leadership. These measures include for society to stop holding female leaders up to a higher standard, for the government to build the necessary infrastructure and legislation, for women to reach for higher-level assignments, and for corporations to make a top-level commitment to support women leaders.

Three theories have been proposed to explain the low ratio of female leadership: "glass ceiling," "motherhood," and "selection process." The glass ceiling argument views the low representation of females in corporate leadership as a remaining gender discrimination issue, given that women were historically discriminated in social rights until the last century. Albrecht, Bjorklund, and Vroman (2003), based on a survey of 19,941,998 individual laborers in Sweden, show that the gender wage gap in Sweden increases throughout the wage distribution and accelerates in the upper tail of the distribution. They suggest that a gender-specific mechanism in the Swedish labor market hinders women from reaching the top of the wage distribution - a glass ceiling effect in top management. After extensive controls for gender differences in age, education (both level and field), sector, industry, and occupation, the authors find that the glass ceiling effect in the raw data persists to a considerable extent. Lyness and Judiesch (1999) study over 30,000 employees from multinational financial services firms in the US. Consistent with predictions based on sex stereotype research, they show that relative to men, women were more likely to be promoted than hired into management positions, and also relative to men, women in higher-level positions received fewer promotions than women in lower levels. Based on a 2-year follow up study with eBay employees, Angier and Axelrod (2014) report that women experience the company in strikingly different ways from men, even though they have equal desire to move up. More women than men feel that they are not understood and their opinions are not listened to.

Intuitively, "motherhood" interrupts career advancement. Bertrand, Goldin, and Katz (2010) conducted a web-based survey on University of Chicago MBA (Master of Business Administration) holders from the graduating classes of 1990 to 2006. They find that although male and female MBAs have nearly identical earnings at the outset of their careers, their earnings soon diverge, with the male earnings advantage reaching almost 60 log points a decade after MBA completion. The divergence is largely explained by higher career discontinuity and shorter work hours for female MBAs, which are largely associated with motherhood.

Finally, existing directors' behavioral habits, such as seeking people similar to themselves in the selection process for new members, might also explain the persistence of low gender diversity. Westphal and Zajac (1995), based on US Fortune 500 firms during 1986-1991, show that powerful chief executive officers (CEOs) seek to appoint new board members who are demographically similar, and therefore more sympathetic, to them. Doldor et al. (2012) examine the appointment process of nonexecutive directors. They show that the intermediaries in this elite labor market, executive search firms, assess candidates not only on their suitability for the role because of the skills they possess, but also on subjective judgments of how they fit in with the current board. The increase in gender diversity is largely due to the $30 \%$ Club-a group of chairpersons who champion gender diversity on boards. 
The overall message from these studies is that the lack of gender diversity could be due to the division of social roles and rational behaviors, as well as discrimination. Economic and cultural factors are important in influencing female career advancement.

\section{Differential Preferences by Gender}

Aside from these social norm explanations, a large amount of literature has demonstrated that men and women substantially differ in their decision making, which may also shed light on gender balance. Croson and Gneezy (2009) summarize results from many economic experiments, identifying robust differences in risk preferences, social (other-regarding) preferences, and competitive preferences. Studies on these preference differences, however, show no conclusive results on any inefficiency associated with female presence. In many cases, there are benefits associated with female presence and gender diversity.

On risk aversion, Sapienza, Zingales, and Maestripieri (2009), based on an experiment with a University of Chicago 2008 cohort of more than 500 MBA students, show that women are generally more risk averse than men. Specifically, they show that higher levels of circulating testosterone were associated with lower risk aversion among women, but not among men. Based on a large survey of directors in Swedish firms in 2006, Adams and Funk (2012) show that female directors, in contrast to findings for the population, are less traditional and security oriented but more risk loving than male directors. Thus, having a woman on the board need not lead to more risk-averse decision making. Eckel and Grossman's (2008) review of experimental measures of risk aversion concluded that although women are found to be more risk averse than men in most studies, studies with contextual frames show less consistent results. Furthermore, consistent with the idea that female managers are not necessarily more risk averse than men, Adams and Ragunathan (2014) find that listed banks with more female directors did not engage in fewer risk-taking activities around the 2007-2009 crisis and did not have lower risk than other banks.

On other social preferences, Adams and Funk (2012) show that female corporate directors in Sweden are more benevolent and universally concerned but less power oriented than male directors. Adams and Ferreira (2009) show that female board directors in US firms during 1996-2003 had better attendance at board meetings and were more likely to join monitoring committees. Consistent with Adams' studies, Srinidhi, Gul, and Tsui (2011) survey 258 controllers of Fortune 1000 firms and find that, correcting for selectivity bias and controlling for other known board, firm, and industry characteristics, there are significantly higher audit fees in firms that have at least one female director and in firms with a higher proportion of female directors on the board. That is, boards with female directors are more likely to demand higher monitoring in the form of more audit effort, ceteris paribus.

On competition preference, Gneezy, Niederle, and Rustichini (2003) show that women may be less effective than men in competitive environments, especially when women have to compete against men rather than in single-sex competitive environments. Hogarth, Karelaia, and Trujillo (2012), however, suggest this ineffectiveness might be exactly associated with lack of gender diversity. They study gender differences in competitive environments by exploiting the "naturalistic experiment" of a television game show where participants are self-selected and there are no gender-specific constraints or discrimination. In multiple rounds, contestants answer general knowledge questions privately. One participant is eliminated or leaves voluntarily at the end of each round. Women earn $40 \%$ less than men and exit the game prematurely at a faster rate, but especially when in a minority. Echoing on the competition externality of team diversity, Apesteguia, Azmat, and Iriberri (2012) use the 2007, 2008, and 2009 editions of the L'Oreal e-Strat Challenge, which includes 37,914 participants from 1,500 
different universities in 90 different countries, to investigate whether the gender composition of teams affects their economic performance. They find that for undergraduates across all performance distributions, three-woman teams are outperformed throughout, but by as much as 0.47 of a standard deviation of the mean at the bottom and by only 0.09 at the top. For MBA students at the top, the best-performing group is two men and one woman.

Studies on gender-specific preferences overall suggest the following: First, female leaders don't make less efficient decisions for corporations than male leaders. Second, women could make better monitors than men. Finally, gender diversity is actually desirable for the best performance in a competitive environment.

\section{The Relation between Gender Diversity and Firm Performance}

While some studies show negative value associated with gender diversity, other research suggests that gender diversity is associated with positive performance, especially when there is not a quota requirement. Carter, Simkins, and Simpson (2003) find significant positive relation for US Fortune 1000 firms in 1997 between the fraction of women or minorities on the board and firm value, after controlling for size, industry, and other corporate governance measures. Adams and Raguathan (2014) show that banks with more gender-diverse boards had better performances during the 2007-2009 crises. Erhardt, Werbel, and Shrader (2003) also show that, for 127 large US public companies during 1993 and 1998, the percentage of women and minorities on boards of directors is positively associated with firms' ROA and return on investment.

Female representation in the boardroom is positively associated with not only financial performance but also accounting quality. Srinidhi, Gul, and Tsui (2011), based on US firms during 2001-2007, find that firms with greater female participation on their boards exhibit higher earnings quality. That is, gender diversity improves the oversight function of the board.

Adams and Ferreira (2009), however, show that the average effect of gender diversity on firm performance is negative for US firms during 1996-2003. They argue that the negative effect is driven by firms with fewer takeover defenses. Consistent with the takeover defense effect, Huang and Kisgen (2013) show that male executives undertook more acquisitions and issued debt more often than female executives in US firms during 1993-2005. Levi, Li, and Zhang (2014), based on S\&P 1500 companies during 1997-2009, also find that each additional female director is associated with $7.6 \%$ fewer bids, and each additional female director on a bidder board reduces the bid premium paid by $15.4 \%$. Their findings support the notion that female directors help create shareholder value through their influence on acquisition decisions.

Another way to address the value of gender diversity is to examine performance changes upon new appointment of female directors. The evidence is again mixed. Farell and Hersch (2005) show that, based on US Fortune 500 data from 1990 to 2000, board gender diversity is positively associated with firm performance, but there is no significant abnormal return on the announcement of a woman's appointment to the board. Dieleman, Qian, and Ibrahim (2013), however, show that new appointment of female directors is positively associated with better firm operating performance compared with appointment of male directors. Campbell and Minguez-Vera (2010) focus on the impact of female directors in Spain during 1989-2001. They find that the stock market reacts positively in the short term to the announcement of female board appointments and that firms' market value is positively associated with female board appointments over the long term, too. 
In short, there is no universally conclusive evidence on whether increasing female representation in boardrooms will improve firms' financial performance. There are large cross-country and cross-firm-group differences. However, studies that support the value-adding notion of female representation in corporate boardrooms seem to outweigh studies that support value-neutral or value-destroying notions after controlling for various latent variables.

\section{Quota Requirement on Gender Diversity}

Should the appointment of women directors be a response to internal or external calls for diversity or based on qualifications? Will a quota lead to younger and less experienced boards, increases in leverage and acquisitions, and deterioration in operating performance? Many European countries have adopted mandatory quotas for gender diversity. Evidence from these natural experiments where quotas are mandated by the government show that quota systems effectively improve diversity, but results are mixed on the value-added from that diversity improvement.

Ahern and Dittmar (2012) examine the effect of the quota requirement on board diversity for 248 publicly listed Norwegian firms during 2003-2009. They find that the 2006 announcement of the quota-a target of $40 \%$ female directors at a time when only $9 \%$ were in place-caused a significant drop in the stock price and a large decline in Tobin's Q over the following years. Despite businesses' fear that there were not enough qualified women to fill the board positions and the poor reaction of the market, Bertrand et al. (2015) show that the new reserved seats were filled with women who are observationally better qualified to serve on boards than the women appointed before, suggesting that there was indeed a glass ceiling stopping qualified women from rising. Matsa and Miller (2013) examine the effect of this same quota introduction on corporate policy decisions. They find that the affected Norwegian firms undertook fewer workforce reductions than comparison firms-other Scandinavian companies that are not affected. The effects are strongest among firms that had no female board members before the quota was introduced and present even for boards with older and more experienced members.

In some other scenarios, even imposing a quota won't help to increase diversity itself, much less the performance. Lukas (2014) studies such a case in Germany. As German corporations have supervisory boards aside from boards of directors, the proposed quota is restricted to supervisory bodies on which there is employee representation. It covers only about 100 of Germany's listed corporations. Thus the policy will affect only a modest share of the workforce.

Different from the quota approach, Australia imposes a mandatory announcement and disclosure rule for appointing directors. Using these data, Adams, Gray, and Nowland (2011) show that the gender of directors appears to be value relevant. On average, shareholders value additions of female directors more than they value additions of male directors. Firms with workplace practices in place to promote workplace equality appear to benefit the most from boardroom gender diversity.

Again, the evidence is mixed on the value effect of mandatory quotas or disclosure rules on gender diversity. There are not only cross-country differences but also differences due to the measurement of performance. There is no theory or evidence supporting the notion that there exists a universally optimal level of female representation for all firms. 


\section{Other Implications}

Employment might be an objective for overall economic performance. Matsa and Miller (2011), based on a survey of US business owners in 2007, find that privately held firms owned by women were less likely than those owned by men to downsize their workforces during the Great Recession, controlling for firm and industry characteristics. Women-owned firms operate with greater labor intensity after the previous recession and are less likely to hire temporary or leased workers. These patterns extend previous findings associating female business leadership with increased labor hoarding.

What about influences on the next generation? Beaman et al. (2012), exploiting a randomized natural experiment in India (a 1993 law that reserved leadership positions for women in randomly selected village councils), show that female leadership in the village influences adolescent girls' career aspirations and educational attainment. Using 8,453 surveys of adolescents aged 11 to 15 and their parents in 495 villages, they find that, relative to villages in which such positions were never reserved, the gender gap in aspirations closed by $20 \%$ in parents and $32 \%$ in adolescents in villages assigned a female leader for two election cycles. The gender gap in adolescent educational attainment is erased, and girls spend less time on household chores. There is, however, no change in young women's labor market opportunities, which suggests that the impact of women leaders primarily reflects a role model effect.

From a management point of view, there are also features that make female leadership desirable. Fitch and Agrawal (2015) suggest that female bosses are more engaging than male bosses. Barsh (2014) believes that women and men leading as equals can fix capitalism's current relentless push for ever-increasing short-term profits and deliver meaningful impact over the long term instead.

In sum, female leadership demonstrates a positive effect on social welfare measurements such as employment and development of young girls. As these social measures are important for economic stability and sustainability, it is necessary to evaluate gender diversity using these measurements, which go beyond short-term indicators such as corporate financial performance.

\section{Asian Countries' Recognition of Gender Diversity Compared with Western Countries}

While the international literature is overall inconclusive on the corporate value effect of gender diversity and the necessity of imposing a diversity quota, it does suggest that gender diversity provides positive value in corporate governance and social dimensions. In Asia, however, gender diversity in corporate boardrooms is low, and there are few studies of this imbalance. The attention to gender diversity has risen in Asia in recent years. A recent report published by the National University of Singapore presents the views of government, the private sector, and civil society on how female leadership will impact development in Asia (Tuminez, and del Mar Garza, eds. 2014). Another report by Korn Ferry International in 2012 provides a description of gender diversity in the corporate boards of Asian countries.

This subsection reviews recent industry and government initiatives and policies to promote

gender diversity in boardrooms, other corporate leadership positions, and firms in general. While many North European countries set quotas for gender diversity in firms, India and Malaysia are the only Asian countries that have done so. On 27 June 2011, the Malaysian Cabinet approved a policy that requires companies with more than 250 employees to have $30 \%$ of senior management positions filled by women by 2016. India's law requires all listed firms to have at least one female on the board by March 2015. Many firms complied with the law by appointing the wives of the controlling owners. 
One-third failed to comply at all. Nevertheless, except for the PRC, whose corporate governance code does not even mention gender as a desirable quality of prospective board members, the other Asian countries show some degree of attention to gender diversity.

Starting on 1 January 2011, the Australian Securities Exchange required listed firms to publicly disclose their gender diversity ratio, establish measurable and individualized objectives and goals, and disclose in annual reports the ratio and the skills and diversity that the board is looking for. Similarly, the Hong Kong Stock Exchange requires firms to disclose and adopt a diversity policy, or otherwise disclose why not to do so. For New Zealand, the stock exchange states that listed firms might soon be required to publicly disclose how many women and minorities they have in senior roles and as directors.

In Singapore, professional-based organizations such as BoardAgender have been established to promote and facilitate the advancement of women into senior management and board positions. In Japan and the Republic of Korea, politicians seem to pay more attention than industry. For example, former Japan Prime Minister Abe suggested a ratio of $30 \%$ female representation in senior management at a time when that figure was only $1 \%$. In the Republic of Korea, legislation was proposed but not approved requiring state-run corporations and other public organizations to raise the ratio of women on their boards to $15 \%$ in 3 years and $30 \%$ in 5 years.

Deriving from the above conceptual discussion, the literature on theory and empirical evidence, and the practices, we can see the need for a better understanding of causes and impacts of female corporate leadership. The evidence is particularly sparse in Asia. In the next three sections, we will empirically assess the situation in Asia.

\section{DATA AND METHODOLOGY}

\section{A. The Data}

Our sample includes 10 economies: Australia; the PRC; Hong Kong, China; India; Indonesia; Japan; the Republic of Korea; Malaysia; New Zealand; and Singapore. For each economy, we include in the analysis the top 100 largest listed firms in terms of their market capitalization during the years 2013 and 2014. These 1,000 sample firms cover the following industries: materials, utilities, financials, real estate, health care, consumer discretionary, industrials, energy, information technology, consumer staples, and telecommunication services. Figure 1 shows the industry distribution of these 1,000 firms, with the largest portion in the consumer discretionary industry and the lowest in information technology. The distributions are similar across countries. As Figure 1 shows, no particular sector dominates the sample. It is hence unlikely that any sector will drive the empirical results. 


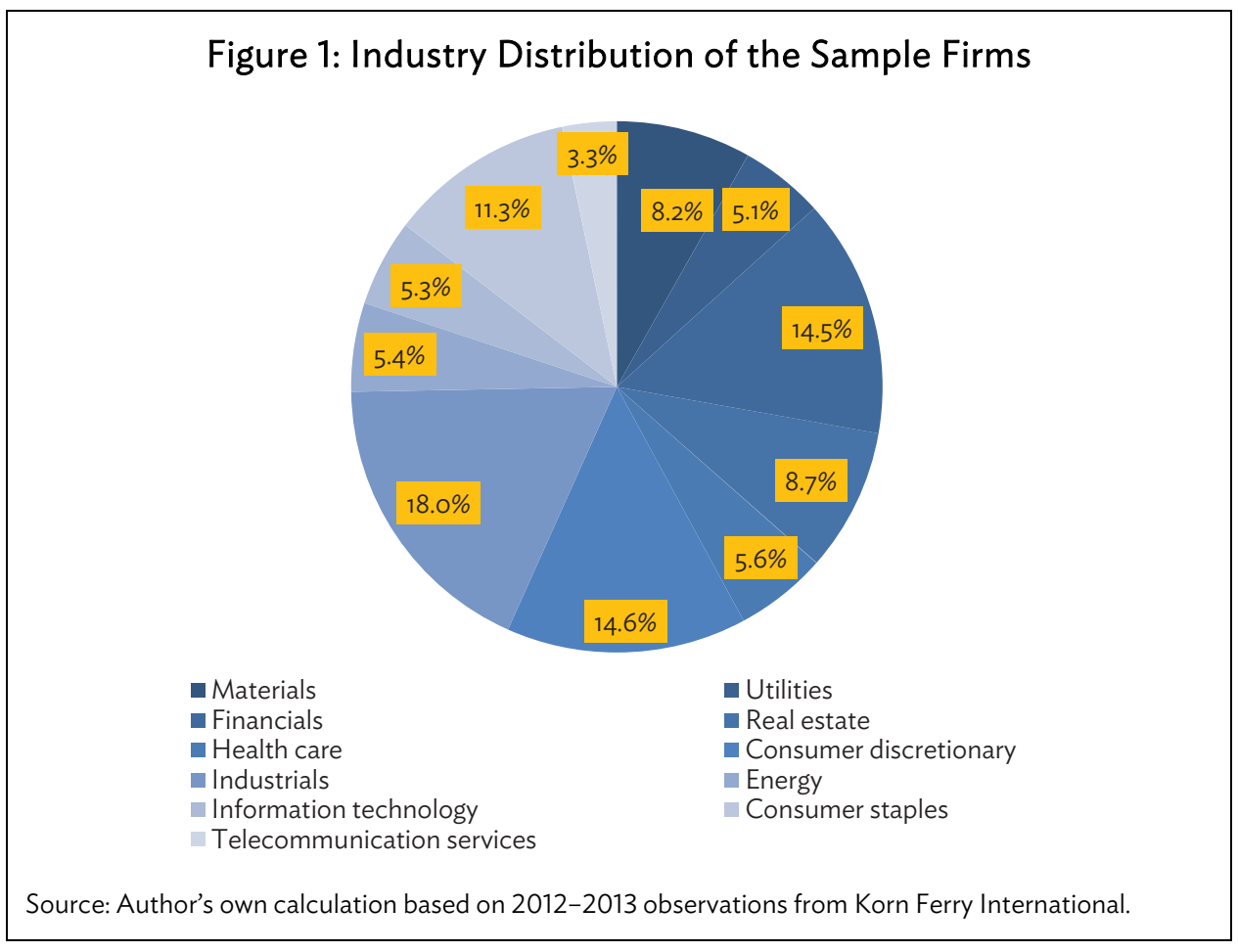

We access the data through the Centre for Governance, Institutions and Organisations (CGIO) that obtains the data from Korn Ferry International. We observe each firm's financials from 2011 to 2014 and board composition in 2012 and 2013. The short time series may not be ideal for analyses to disentangle causalities. We therefore conduct robustness tests using a panel of Singaporean firms with 7 years of observation. The financial variables in the sample include ROA, ROE, current ratio, leverage, coverage ratio, market capitalization, stock prices, assets turnover ratio, profit margin, and cash flow ratio.

For board composition, we observe each board member's relation with the firm (independent or executive member), age, education, gender, ethnicity, participation in board committees, and attendance at board meetings. For 2012, we observe the board characteristic values from firms' reports in December 2011 or June 2012, and the 2013 values are from reports in March, June, September, and December.

\section{B. Empirical Methods}

We measure gender diversity with female representation (\%) and an indicator for at least one female on the board. For the descriptive part, we also include indicators for females in a variety of board committees and an indicator for females as corporate leaders, e.g., chairperson or CEO. In relating gender diversity to performance, we also look at new appointments of female directors.

We measure firm performance with ROA and ROE, and market valuations. The 1,000 sample companies studied have an average ROA of $6.2 \%$ and ROE of $13.3 \%$.

In describing the gender diversity situation in Asian boardrooms, we use descriptive statistics and univariate comparison. In analyzing the relation between gender diversity and firm performance, we use regression analysis in addition to the descriptive comparison. Finally, we use two-stage least- 
squares (2SLS) and Heckman's Lamda approaches to disentangle the causalities, e.g., whether it is the firm's past performance determining the decision to hire women, or the decision to hire women affecting future firm performance. In the first stage, we investigate the determinants of gender diversity using the predetermined firm, industry, and country characteristics; in the second stage, we predict future firm performance with the actual gender diversity in firms while controlling for the predicted gender diversity calculated from the first-stage estimation. With the predicted gender diversity controlled, the estimated coefficient on the actual gender diversity in the second stage captures the financial effect of the unexpected change in female leadership. A significant coefficient on the gender diversity measurement in this setting hence suggests that gender diversity has predictive power on firm performance.

Specifically, we run the following regressions:

$$
\begin{aligned}
& \text { Gender Diversity }_{i t}=a+b^{*} \text { performance }{ }_{i t-1}+c^{*} I V_{i t-1}+d^{*} \text { Char }_{i t-1} \\
& + \text { Industry } F E+\omega_{i t} \\
& \text { Performance }_{i t+1}=\alpha+\beta^{*} \text { Gender diversity }{ }_{i t}+\gamma_{0}^{*} \text { predicted gender diversity }{ }_{i t} \\
& +\gamma^{*} \text { Char }_{i t}+\text { Industry FE }+\varepsilon_{i t+1}
\end{aligned}
$$

where $i$ and $t$ denote for firm and year. Firm characteristics include total assets, age, leverage, and profit margin. Note that the above two-stage analysis is equivalent to Heckman's Lamda approach when gender diversity is measured by a discrete choice variable, such as whether a female director is appointed and whether there is at least one female on the board.

We need instrument variables that are correlated with gender diversity measurements but not correlated with performance measurements in the first stage. For the firm-level instrument, we use the ratio of female presence on the board in the past year. For the country-level instruments, we use gender equality measurements that potentially affect the demand and supply of female corporate leaders: specifically, the gender equality in college entrance (the number of female college registrants over the number of male college registrants), female labor force participation (\%, the number of females in the labor force over the total number of females of working age), wage equality (\%, the average female wage over the average male wage on similar jobs), and the equality in infant survival (\%, girls' survival rate over boys' survival rate). The data are from the World Bank's Gender Equality Data and Statistics.

Formal education and working experience are critical in developing managerial and leadership skills. The first two instruments, college education and labor participation by females, hence can be potential determinants of the supply of female corporate leaders. Using data from 73 developing countries, Amin and Islam (2015) show that countries with a higher proportion of female top managers also have higher enrollment rates for women relative to men in primary, secondary, and tertiary education. The market demand of the female leadership, however, is hard to measure directly. Nevertheless, as increased demand for female talent brings better prospects for girls-which encourages better care of girls by the parents-we can use the girls' infant survival rate (benchmarked to boys') to proxy for the demand. Finally, as wage is an endogenous part of the labor market, wage equality can affect and be affected by both the demand and supply of female workers and leaders. A pay gap between men and women is a reality, even in countries with legal mechanisms to reduce the gap. Bernard (2014) reports that equality-related pay analysis in US firms only responds to litigation risk, and the process is opaque. 


\section{IV. $\quad$ EMPIRICAL RESULTS ON GENDER DIVERSITY}

\section{A. Female Representation}

Figure 2 presents the ratio of female directors in boardrooms by country and year. As of 2013, Australia had the region's highest female representation on its companies' boards, at $18.6 \%$. The corporate boards of the Republic of Korea (2.1\%) and Japan (3.1\%) had the least representation by women.

It is a general trend that female representation in boardrooms is increasing. Based on the full sample, the average female representation on boards was $8 \%$ in 2012 and increased to $9.4 \%$ in 2013. The greatest improvements in percentage points were in New Zealand (4.5\%) and the PRC (4.2\%). The ratios in Malaysia and the Republic of Korea, however, decreased.

Figure 2: Female Representation on Boards in Asia and the Pacific

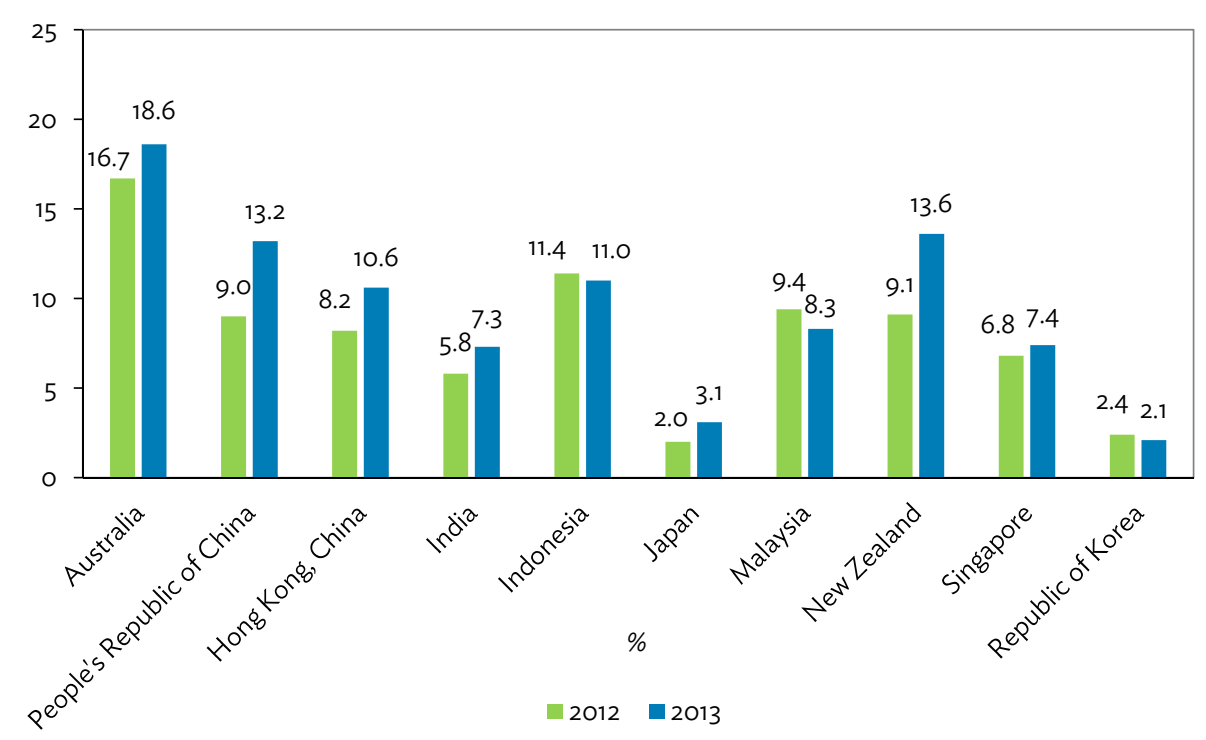

Source: Author's own calculation based on 2012-2013 observations from Korn Ferry International.

In Figure 3, we present, by country and year, the percentage of all-male boardrooms. The Republic of Korea has the highest percentage (84\%) while Australia has the lowest (9\%). In 2012, 6 of the 10 studied economies, including developed countries such as Japan, New Zealand, and Singapore, had all male directors in more than half of the boardrooms. Not a single boardroom was all female.

All-male boards nevertheless decreased across the region from 2012 to 2013. New Zealand again made the greatest improvement, by $18 \%$. The Republic of Korea and Malaysia were the exceptions with little improvement. Indonesia is a further outlier, with an increase in all-male boards from 2012 to 2013. 


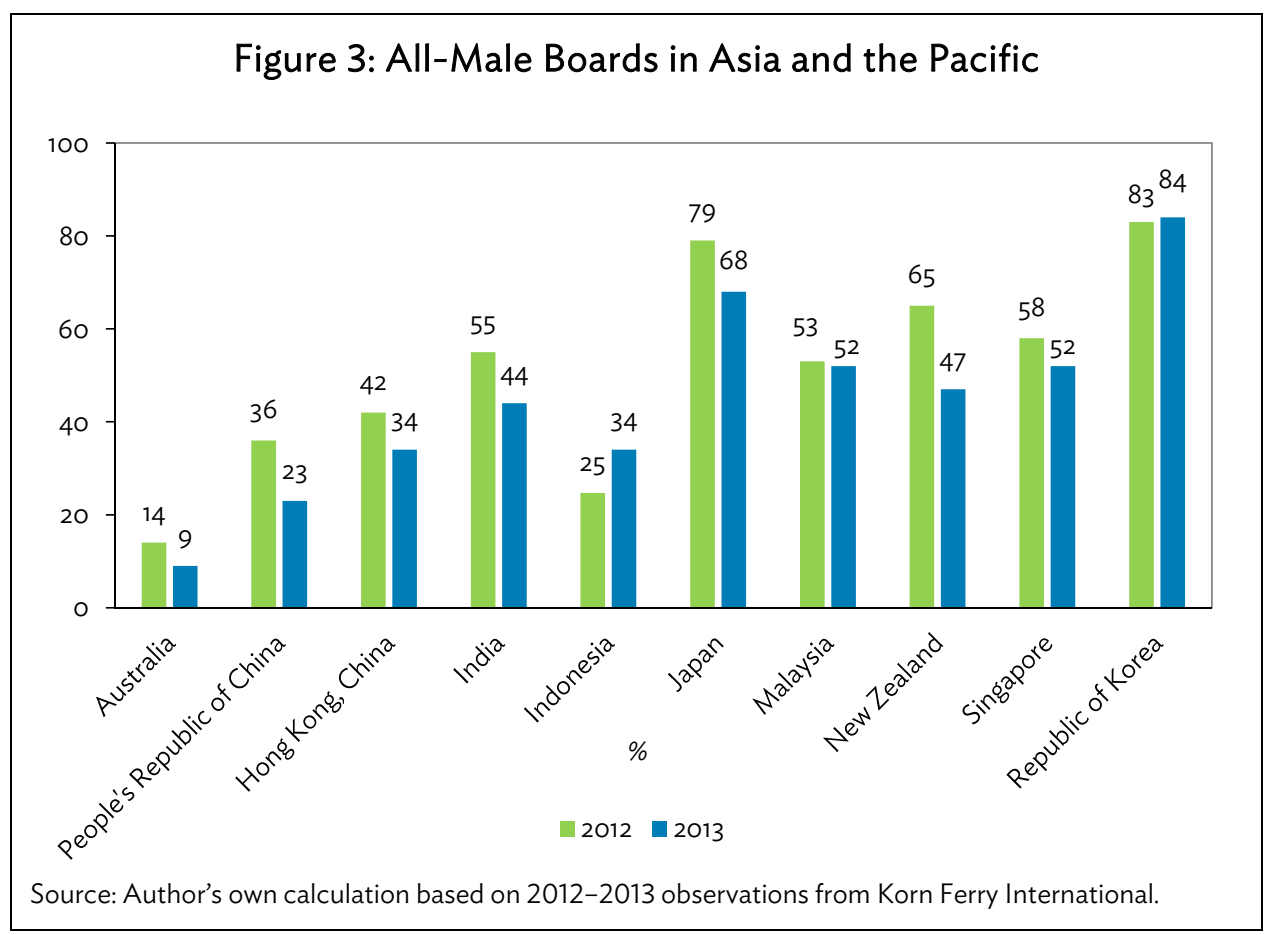

Although the proportion of all-male boards has decreased, for each board with female directors, the percentage of female representation is small: generally a quarter or less. Figure 4 reports the percentage of boards according to the percentage of female representation. For example, $55 \%$ of Indian boards have less than $25 \%$ female representation, $1 \%$ has $25 \%-50 \%$, and the rest have no female representation at all.

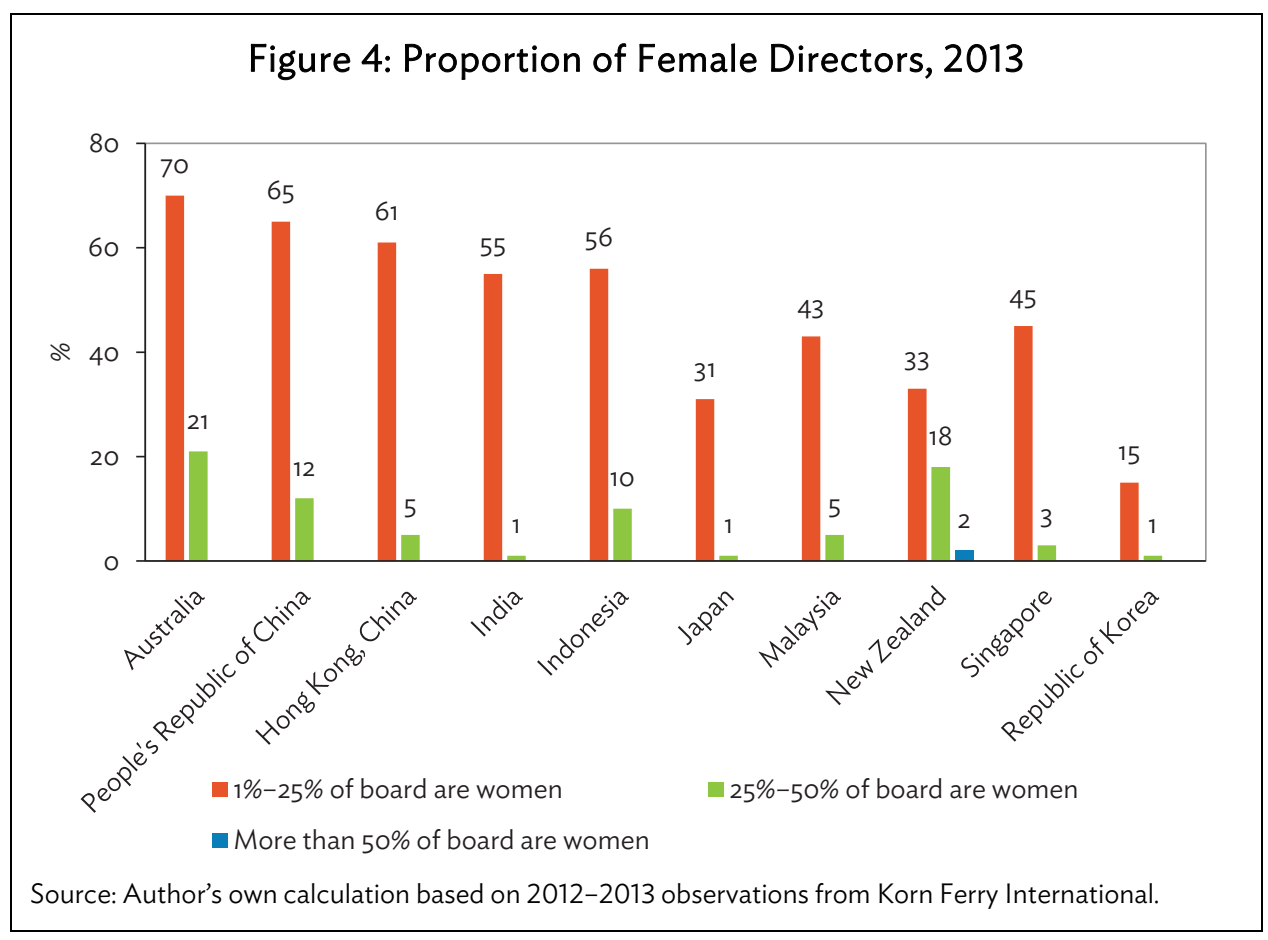


Female boardroom representation might be correlated with the female density in the profession. In Figure 5, we report female representation by sector. Without surprise, health care has the highest representation of female directors at $13.6 \%$. The industry sector, which has the most sampled companies in the study, has the lowest representation at $5.8 \%$. Traditionally, health care has been a female-dominated industry, while the industrial, information technology, and material sectors are dominated by men. In terms of absolute numbers, the finance sector was found to have the most board seats occupied by women (194).

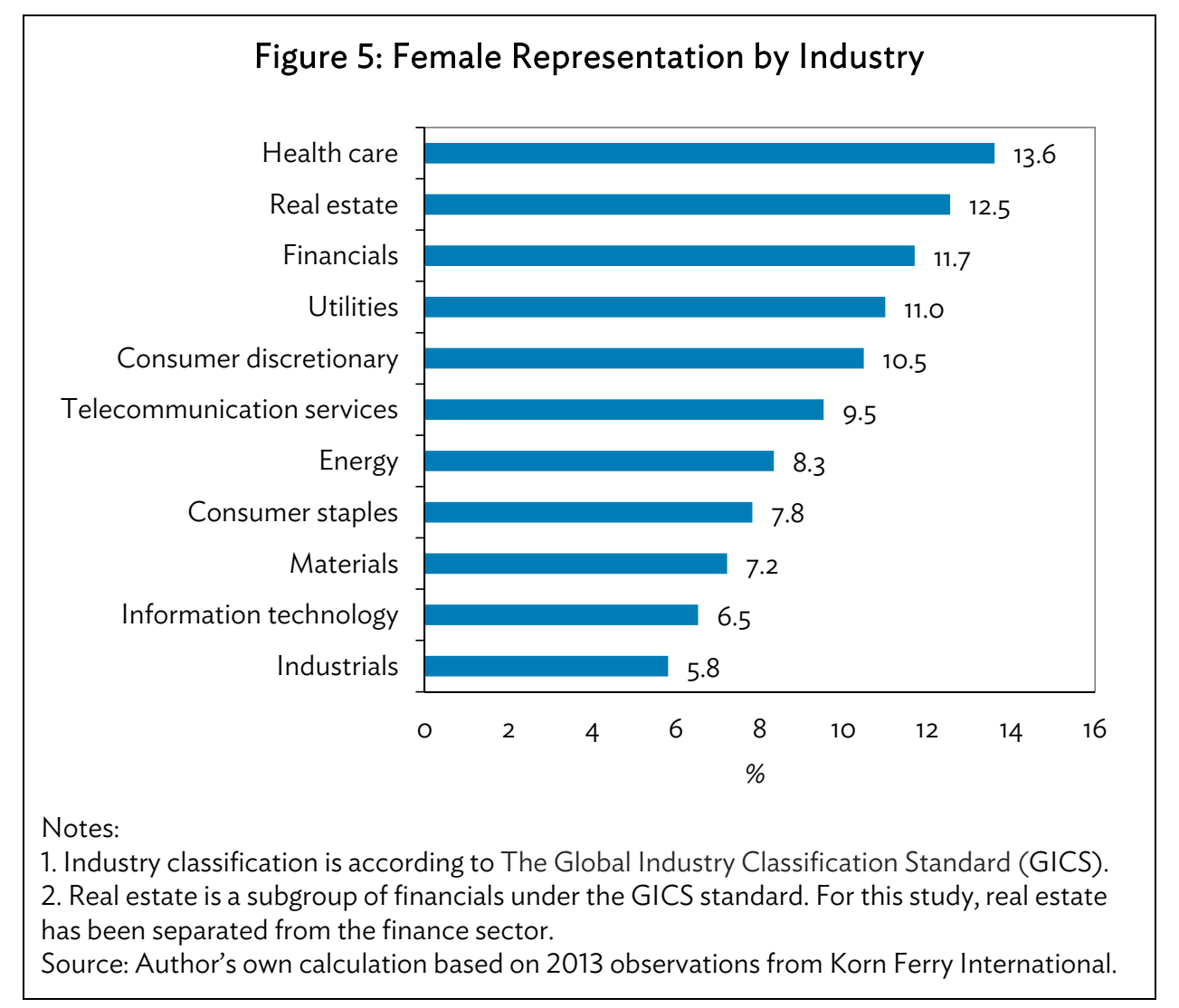

\section{B. Female Leadership in Corporations}

We also look at the sample for women in top leadership positions. As shown in Figure 6, among the 10 economies, only Australia and New Zealand have at least 10\% of their female directors holding key leadership roles as CEO or board chairperson. New Zealand has the highest percentage of female board chairpersons (7.3\%), while the PRC has the highest percentage of female CEOs (5.6\%). In contrast, there are no women in either position in the top 100 companies in Japan, and none of the top companies in India and the Republic of Korea have women as board chairpersons. 


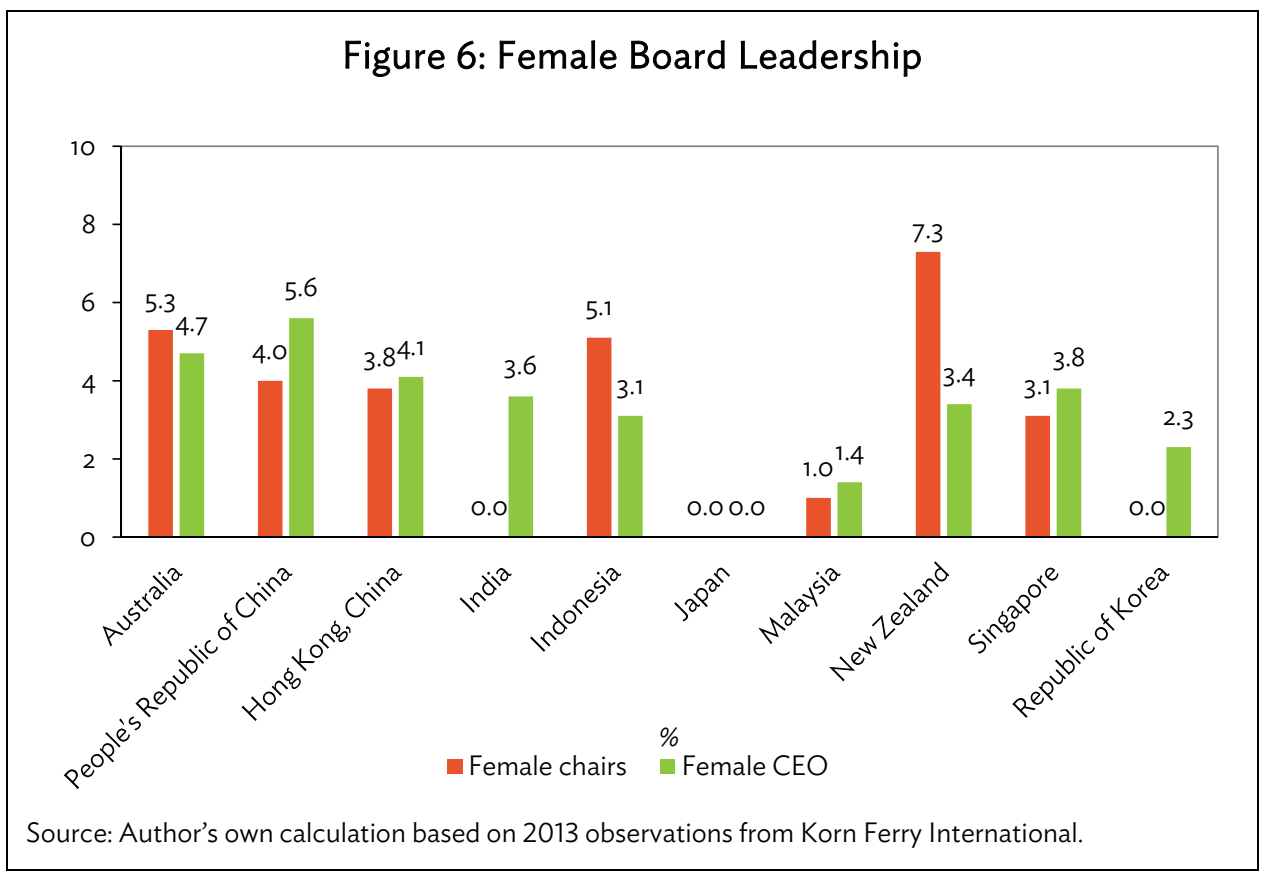

With the increase in female representation on boards in Asia and the Pacific, the question is then, which type of directorship is held mostly by women. Figure 7 reports female board representation by type of director: executive director, nonexecutive director, and independent director. For example, while $18.6 \%$ is the overall female representation for all directors, $23.5 \%$ of Australian independent directors are females and $4.3 \%$ of executive directors are females. For most of the economies, female representation among independent directors is comparable or higher than their representation as executive directors or nonexecutive, nonindependent directors. The percentage is particularly high for Australia, Japan, and New Zealand. For example, in Japan, although the female representation of board directors is only $3.1 \%$, their representation of independent directors is $13.1 \%$.

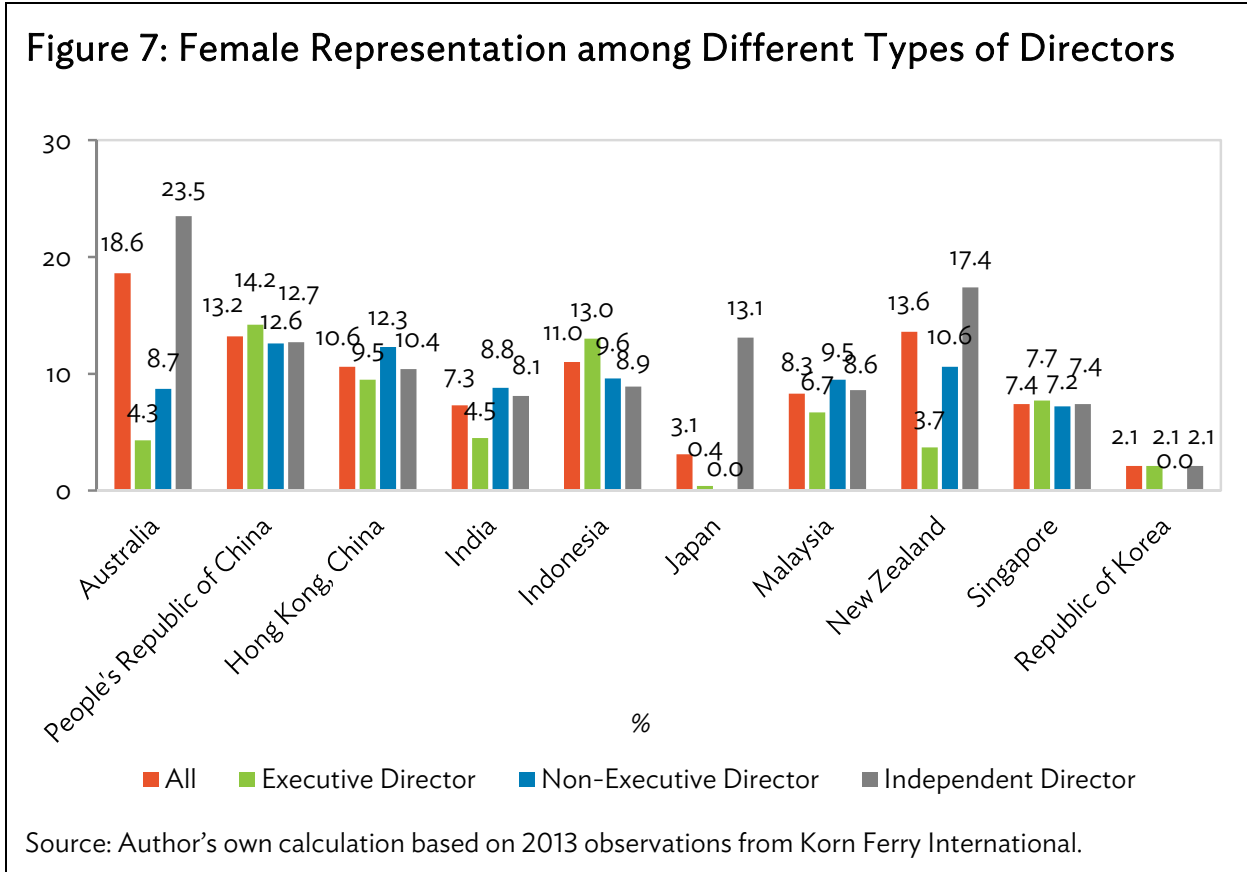




\section{GENDER DIVERSITY AND FIRM PERFORMANCE}

\section{A. Gender Diversity and Performance-Univariate Comparison}

To understand the relation between gender diversity in corporate boardrooms and the performance of those corporations, we start by comparing financial performance between groups of firms that differ in their boardroom gender diversity. We compare firms' ROA and ROE, categorized by whether the firm has at least one female on the board. As Figure 8A shows, in the pooled full sample and half of the countries, firms with at least one female on the board outperform firms that have all-male boards. For example, based on the 1,000-firm sample, the former have an ROA of 6.6\% while the latter have 5.7\%, a discrepancy of $0.9 \%$. The discrepancy is the largest in New Zealand, where all-male boards underperform by $3.2 \%$, followed by the PRC at $2.1 \%$. In Australia, Indonesia, Japan, Malaysia, and the Republic of Korea, however, all-male boards seem to outperform.

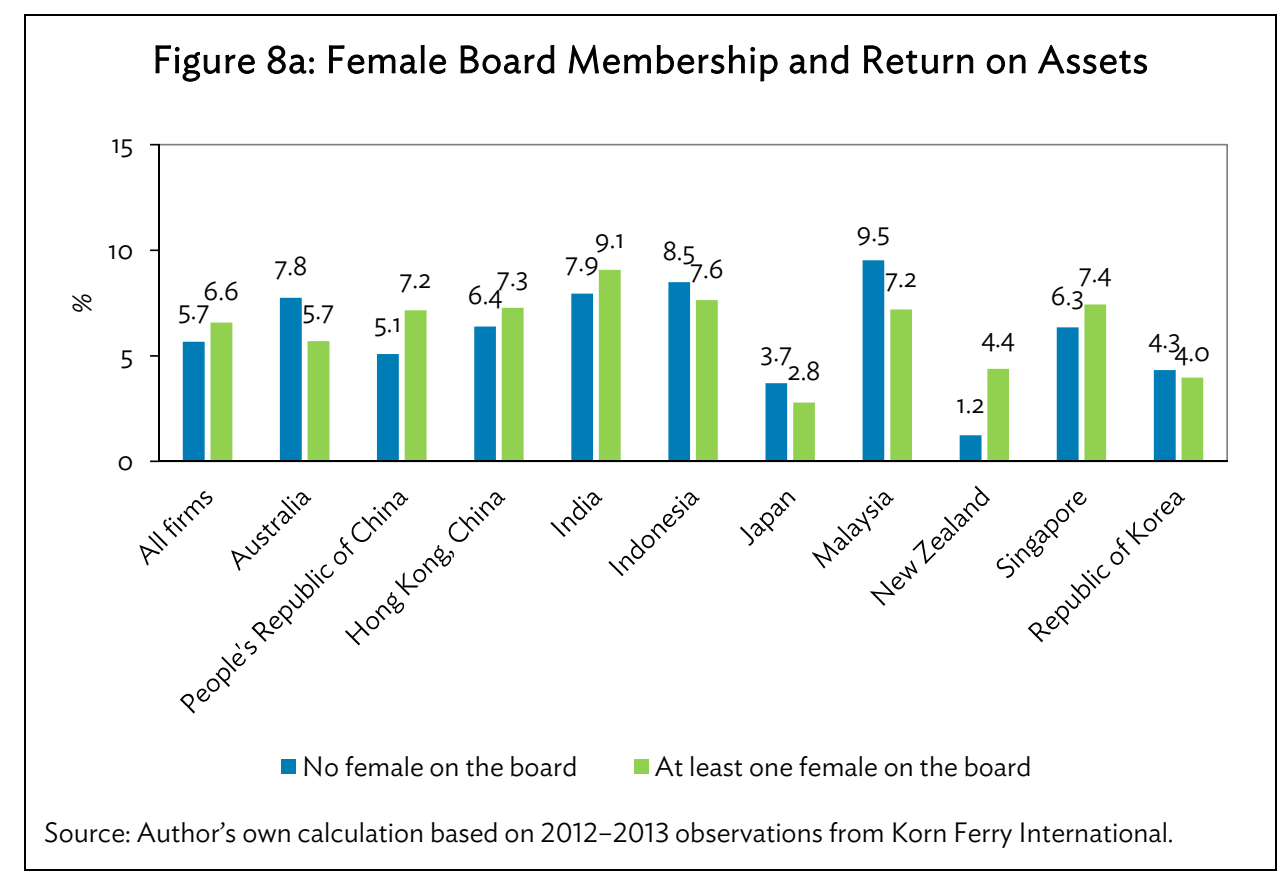

The value-adding feature of having at least one female on the board is more obvious in terms of both magnitude and frequency when we measure performance of ROE. As Figure 8B shows, the discrepancy of performance between the two groups of firms in the full sample is 3.5\% for ROE versus $0.9 \%$ for ROA. The largest discrepancy is in the PRC with $4.6 \%$ ROE. Moreover, there are only three countries where all-male boards outperform more diverse boards: Australia, Japan, and Malaysia. In the full sample and the other seven countries, firms with at least one female outperform firms with allmale boards. 


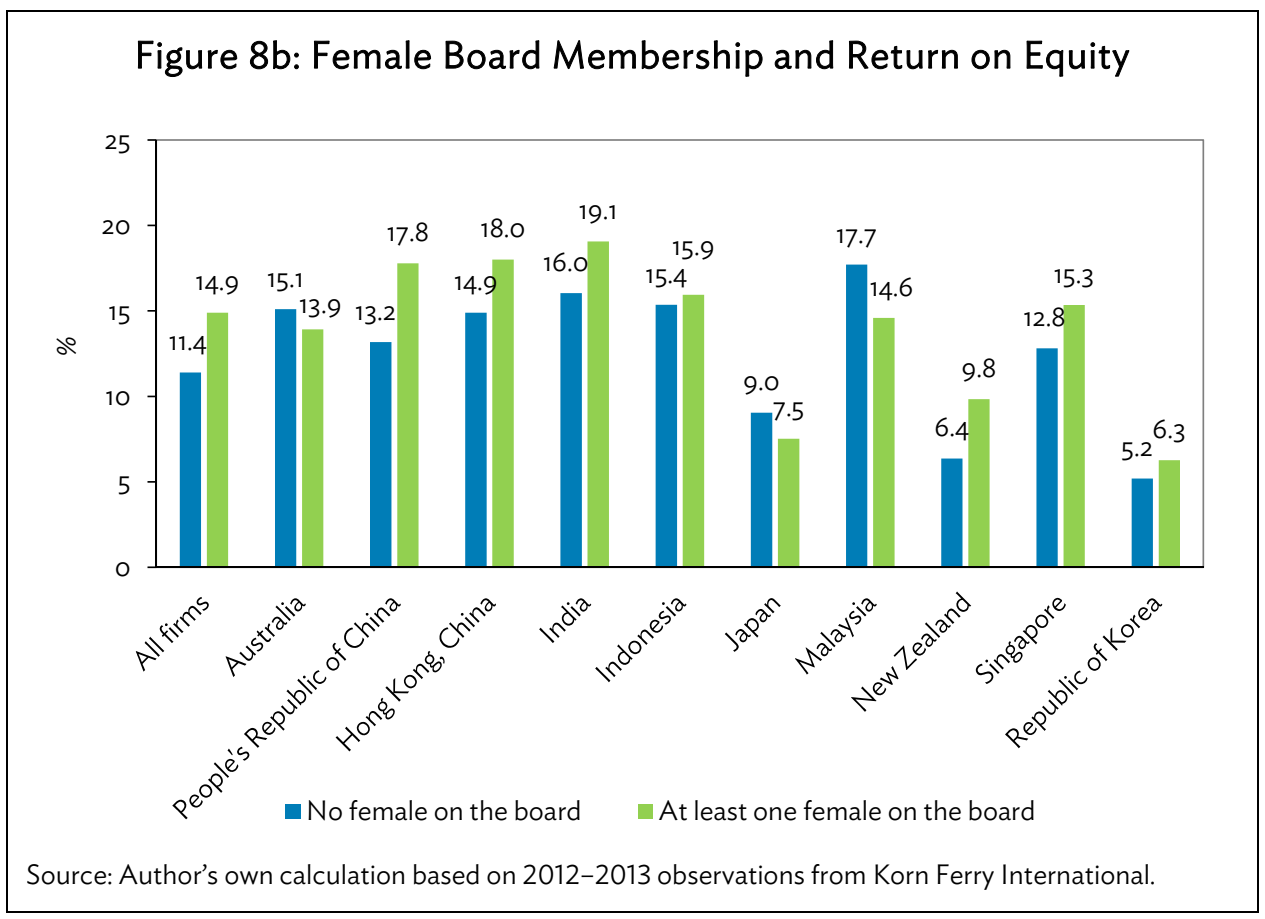

The stock market performance, however, shows almost the opposite effect. As Figure 8C presents, except in the PRC and the Republic of Korea, where firms with at least one female board member outperform firms with all-male boards, the relation between a female presence on the board and stock returns is negative in the rest of the countries. The magnitude of stock market underperformance in firms with at least one female is the largest in Indonesia by $26.3 \%$ and then Australia by $21.4 \%$.

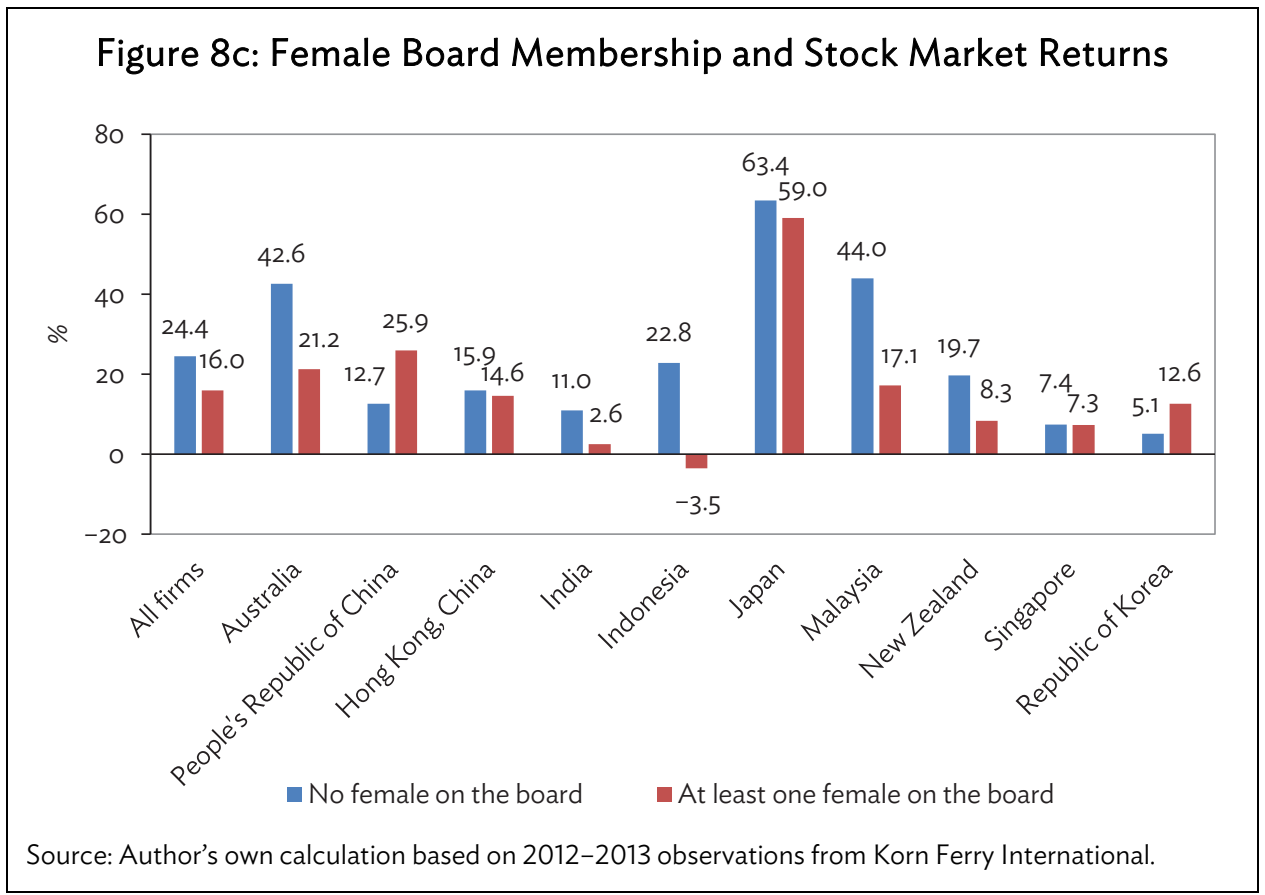


It is possible that the relation between gender diversity and firm performance is neither linear nor homogeneous across industries. We therefore divide firms into four groups: those with no females on the board, those with 0\%-10\% female representation, those with $10 \%-25 \%$, and those with female board representation above 25\%. We then compare these firms' performance at the end of 2013 by industry.

As Figure 9A shows, the materials industry is the only one where firms with all-male boards do not underperform firms that have females on the board. In three of the 11 industries-industrials, financials, and information technology-the best-performing group are firms that have more than 25\% of board members as females. In five industries, the best performers were firms with $10 \%-25 \%$ female board membership; in the remaining two, the best performers were those with boards that were 0\%$10 \%$ female.
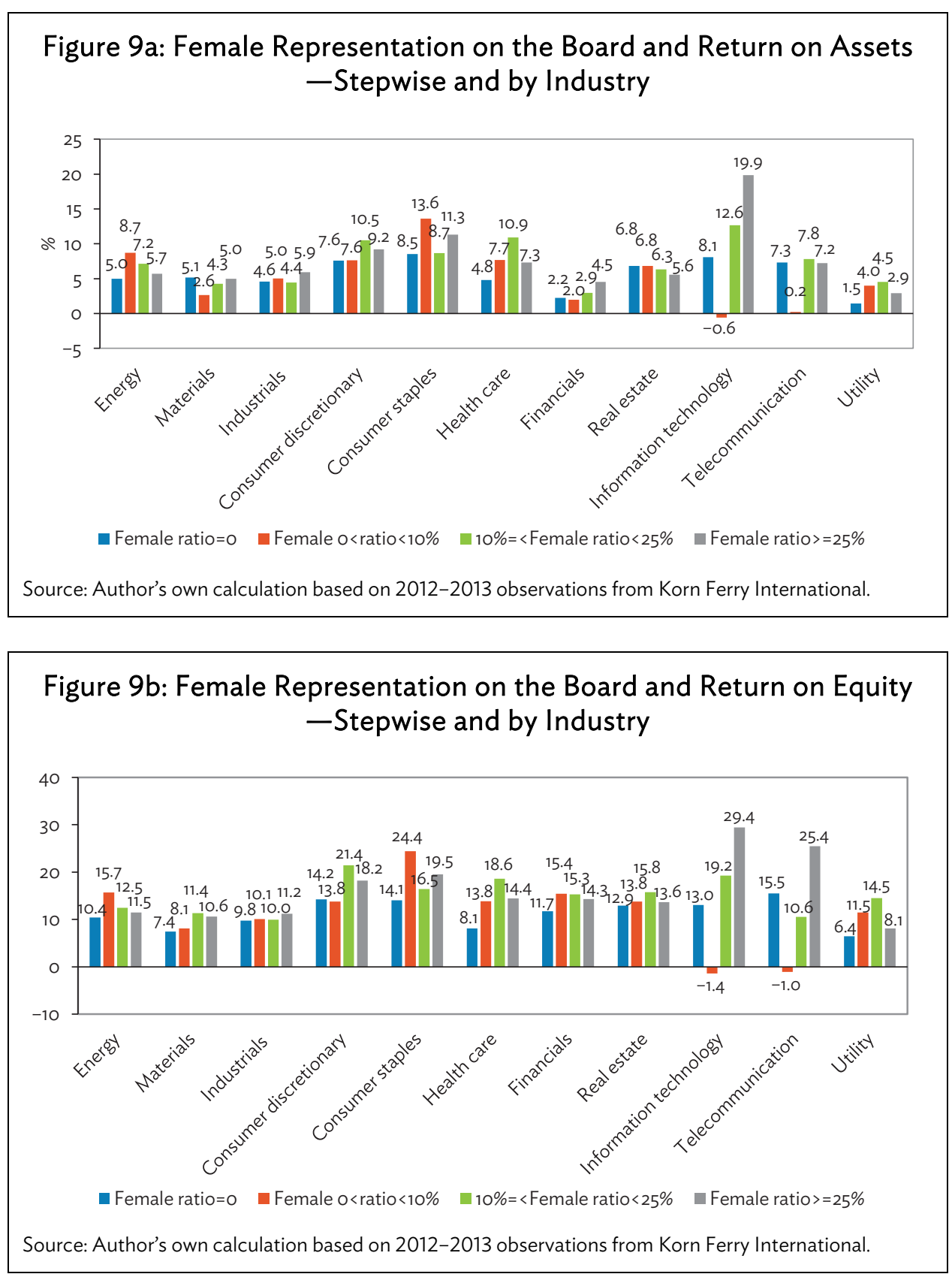
The pattern for ROE in Figure 9B is mostly similar to the pattern for ROA in Figure9A. Firms with all-male boards in the materials industry, however, underperform just as they do in the other industries.

Stock market returns show very different patterns in ROA and ROE. First of all, in five of the 11 industries, the worst-performing group is firms that have at least one female director on the board. The case of the telecommunication industry is particularly striking. While Figure 9B shows the best ROE for firms that have more than $25 \%$ female representation on the board, Figure $9 \mathrm{C}$ shows the worst stock market returns for them. The energy industry shows a similar pattern for firms with a female ratio of 0\%-10\%. In the consumer staples industry, the higher the female representation, the lower the stock market returns. In health care and information technology, stock market returns are highest for firms that have all-male boards. However, the best-performing groups in the energy, consumer discretionary, and financial industries are firms with more than $25 \%$ female board members.

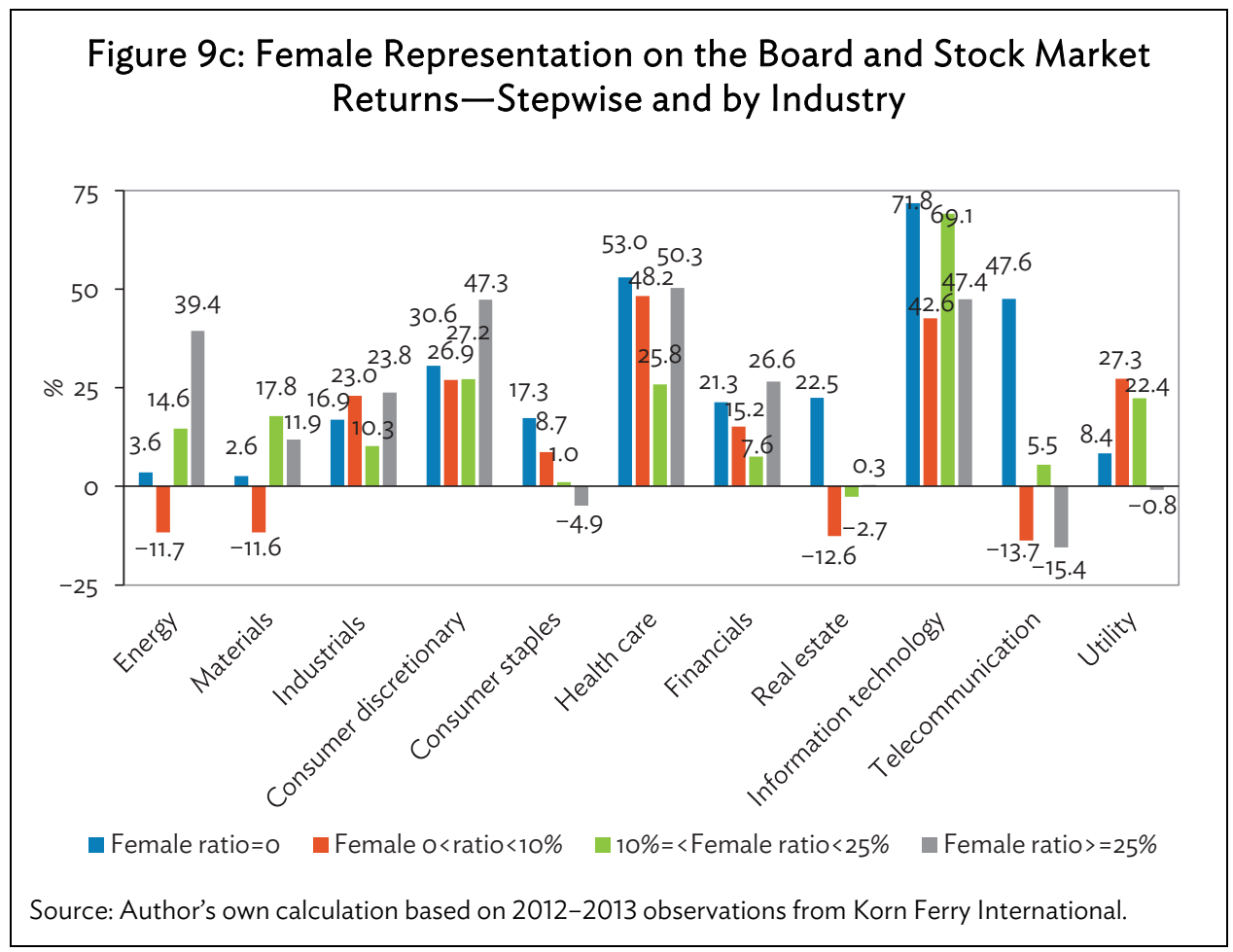

\section{B. Board Member Appointment and Firm Performance}

Another approach to assess the effect of board diversity on firm performance is to examine the performance following appointment of female directors. We compare ROA, ROE, and stock market returns at the end of 2013 for firm groups categorized by whether there is a female director(s) departure, appointment, or no change from June 2012 to June 2013. As Figure 10 shows, firms that appointed at least one female director during this period have the highest ROA at $6.9 \%$. This group also has the highest female director ratio on average. Firms that have no change in the number of female directors have the lowest ROA. This group also has the lowest ratio of female directors. When we measure financial performance with ROE, the worst-performing group is firms with no change in the number of female directors, but the other two groups' ROEs are similar. In fact, returns are slightly higher in the group where net departure of female directors occurred. 
Although comparisons within individual countries might provide a better understanding of the effects of turnover of female directors, there are only 43 firms with net departures and 82 with net appointments of female directors in the full sample. This small sample, if further divided by 10 countries, will result in a small sample size with low reliability of statistical inferences.

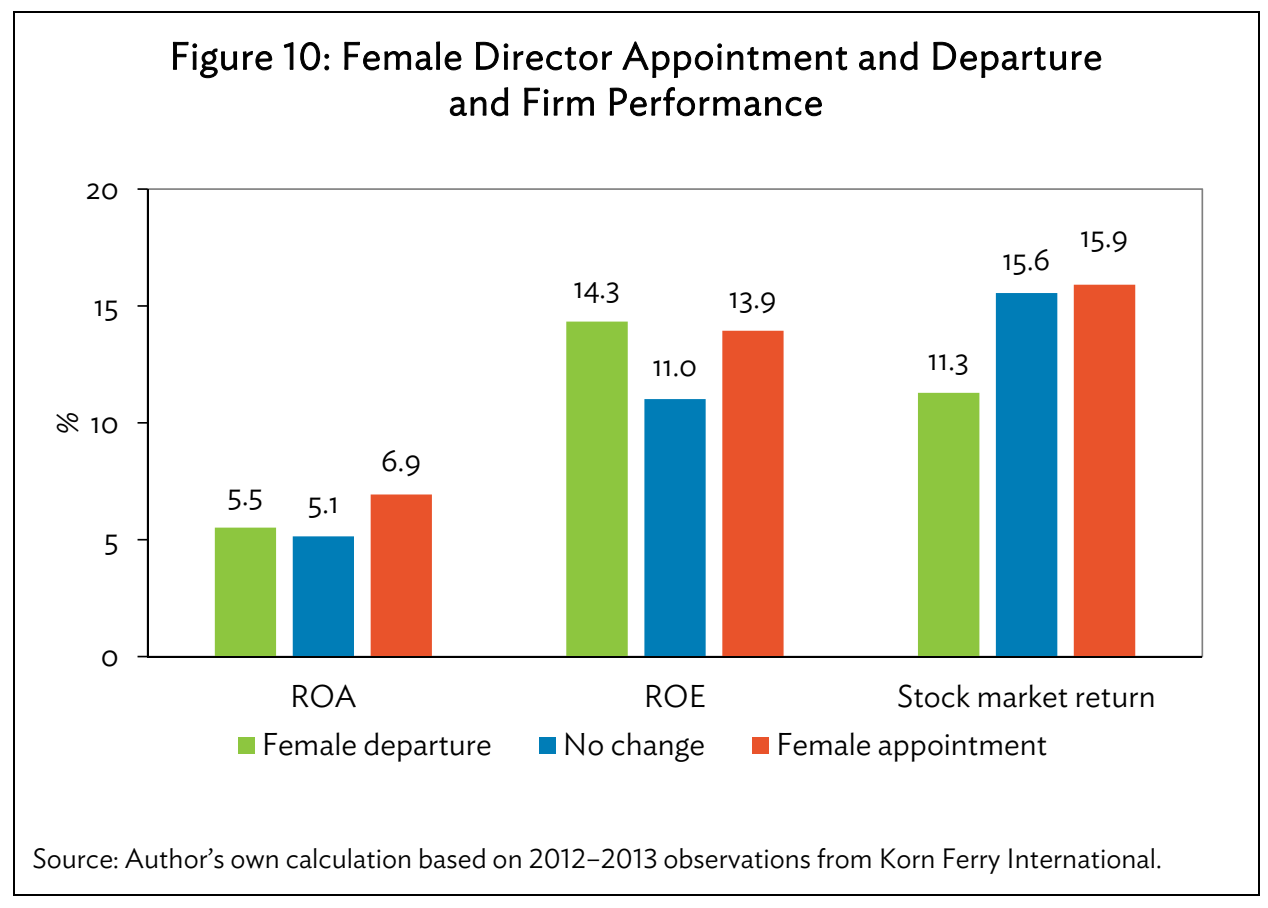

For comparison, we also examine firm performance followed by turnover of male directors. As Figure 11 shows, the departure, appointment, or change of male directors does not appear to affect subsequent firm performance. The different effects of female versus male director turnover on firms' financial performance suggest that appointing a new female director might be relatively more value generating than appointing a new male director, based on this sample.

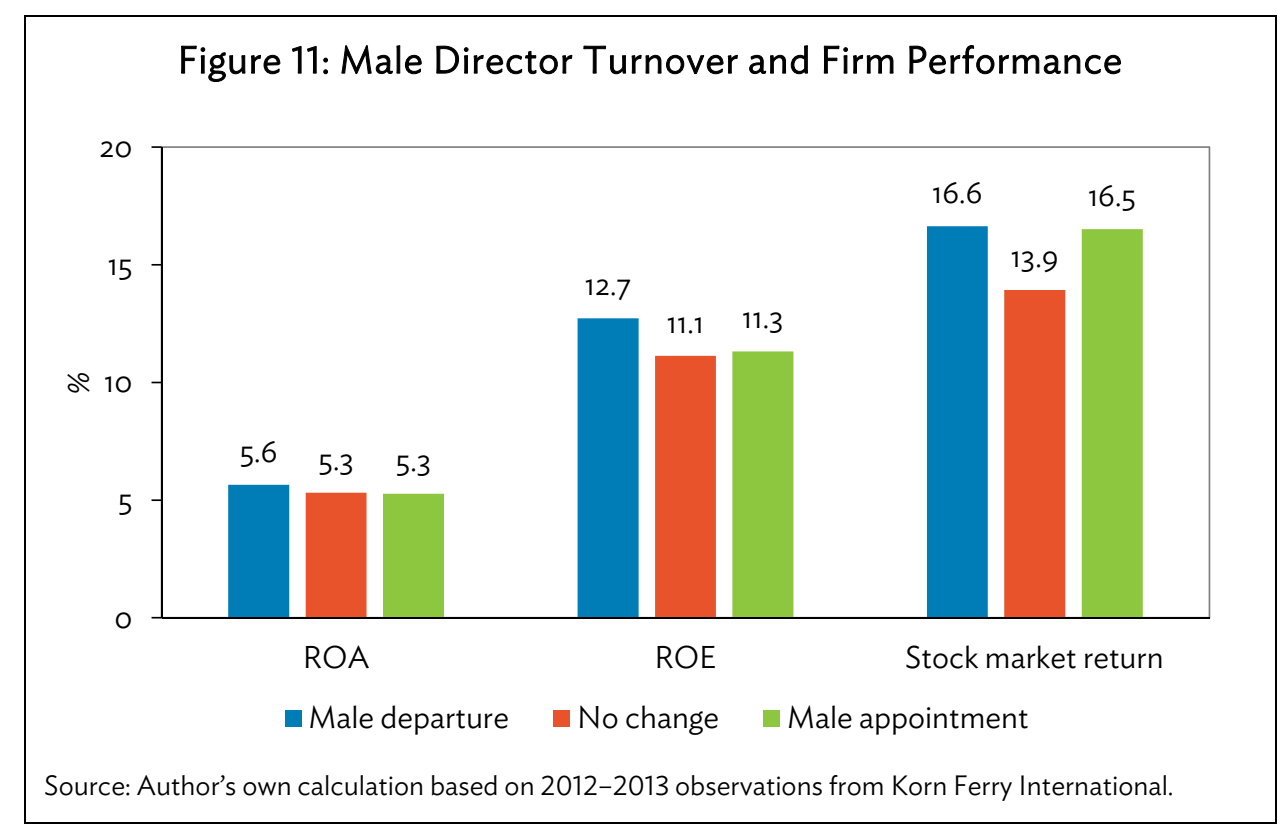


Believing the preferential or behavioral differences between men and women, one may guess that it is easier for a female director to exercise her differences and to generate synergies when there is already at least one other female on the board. To assess this conjecture, we divide the firms that appointed new female directors during June 2012 to June 2013 into three groups: firms whose number of female directors on the board rose from zero to one, from one to two, and from two to more. We then compare these groups' performance following these appointments. As Figure 12 shows, the firm groups that increased the number of female directors from one to two outperform the other two groups in all three performance measures. The magnitude of the outperformance is particularly large for the stock market returns by $10.4 \%$ and $13.6 \%$, respectively. This nonlinear stepwise relation between the number of female directors and firm performance supports the conjecture of positive scale effect of multiple female directors on the same board, but questions the efficiency of femaledominated boardrooms.

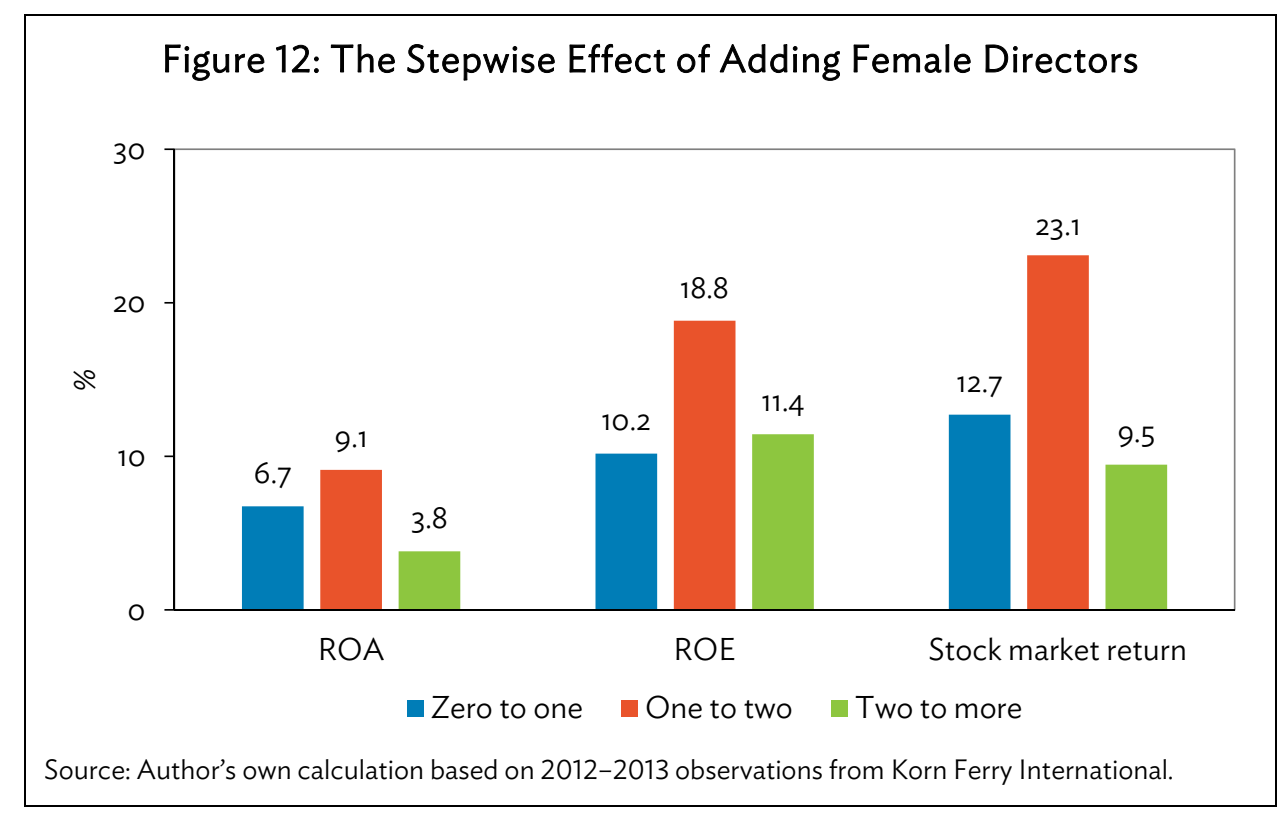

\section{Controlling for Firm and Industry Characteristics}

Univariate comparison has omitted other variables that affect performance. The omission becomes a problem if these variables are correlated with gender diversity. In this section, we use regressions to control for firm and industry characteristics. We conduct the regressions in the full sample with country fixed effects and for each individual country separately.

In Table 2, we use gender diversity, firm characteristics, industry, and country fixed effects to explain firms' financial performance in the next year. The coefficients of gender diversity on performance and their corresponding t-statistics denoting the significance are reported. Each pair of coefficient and t-statistics in brackets is from an independent regression with the full sample. That is, the table is a summary of nine regressions. We find that firms' ROA and ROE are positively associated with female ratio on the board and appointment of new female directors. For example, a $1 \%$ increase in the female director ratio is associated with a $4.38 \%$ increase in firms' ROA in the next year. The stock market's view on gender diversity is, however, mixed. Although firms with at least one female on board outperform firms with all-male boards by $5.38 \%$ in stock returns, the response to the appointment of new female directors on the market valuation is negative. 
Table 2: Gender Diversity and Financial Performance-Full Sample

\begin{tabular}{lccc}
\hline & $\begin{array}{c}\text { Y: Return on Assets } \\
\text { in the Next Year }\end{array}$ & $\begin{array}{c}\text { Y: Return on Equity } \\
\text { in the Next Year }\end{array}$ & $\begin{array}{c}\text { Y: Stock Market Returns } \\
\text { in the Next Year }\end{array}$ \\
\hline Female ratio of directors & $4.38^{*}$ & 0.43 & -12.89 \\
At least one female on board & {$[1.82]$} & {$[0.07]$} & {$[-1.17]$} \\
& $0.68^{*}$ & 0.62 & $5.38^{* * *}$ \\
Appointing new female directors & {$[1.66]$} & {$[0.50]$} & {$[2.88]$} \\
& 1.65 & 3.19 & $-9.81^{* * *}$ \\
Firm characteristics & {$[1.47]$} & {$[0.81]$} & {$[-2.85]$} \\
Industry fixed effects & Yes & Yes & Yes \\
Country fixed effects & Yes & Yes & Yes \\
\hline
\end{tabular}

Notes: Figures in brackets are the t-statistics of the coefficient estimates; * **, and ${ }^{* * *}$ denote significance of $10 \%, 5 \%$, and $1 \%$, respectively.

Source: Author's calculations.

Similar to the full sample results, regression results at the individual country level show differences in performance measurement. There are also large cross-country differences. Due to space limitations, we will not report all 90 regressions but will focus on the stock market returns, and in particular, the significant ones. As Table 3 shows, the relationship between gender diversity and stock market performance is puzzling. While firms with at least one female board member consistently outperform firms with all-male boards in most countries, market valuation reactions to the appointment of new female directors are mostly negative. Even more puzzling, the PRC displays a pattern completely opposite of the other countries.

Table 3: Gender Diversity and Stock Market Returns-by Individual Economy

\begin{tabular}{lccccccc}
\hline \multicolumn{7}{c}{ Y: Stock Market Returns of the Firm } \\
\hline & $\begin{array}{c}\text { People's } \\
\text { Republic } \\
\text { of China }\end{array}$ & $\begin{array}{c}\text { Hong Kong, } \\
\text { China }\end{array}$ & Japan & Malaysia & $\begin{array}{c}\text { New } \\
\text { Zealand }\end{array}$ & Singapore & $\begin{array}{c}\text { Republic } \\
\text { of Korea }\end{array}$ \\
\hline $\begin{array}{c}\text { At least one } \\
\text { female on } \\
\text { board }\end{array}$ & $-20.77^{* *}$ & $11.15^{* * *}$ & & $15.00^{* * *}$ & & $16.49^{* * *}$ & $8.95^{* * *}$ \\
$\begin{array}{c}\text { Appointing new } \\
\text { female } \\
\text { directors }\end{array}$ & {$[-2.24]$} & {$[2.42]$} & & {$[2.46]$} & & {$[3.88]$} & {$[2.68]$} \\
$\begin{array}{c}\text { Firm } \\
\text { characteristics }\end{array}$ & $53.82^{* * *}$ & $-17.15^{* * *}$ & $-16.12^{* * *}$ & & $-21.52^{* * *}$ & & \\
$\begin{array}{c}\text { Industry fixed } \\
\text { effects }\end{array}$ & {$[4.79]$} & {$[-3.69]$} & {$[-2.54]$} & & {$[-2.41]$} & & \\
$\begin{array}{c}\text { Country fixed } \\
\text { effects }\end{array}$ & Yes & Yes & Yes & Yes & Yes & Yes & Yes \\
\hline
\end{tabular}

Notes: Figures in brackets are the t-statistics of the coefficient estimates; ${ }^{* * *}$, and ${ }^{* *}$ denote significance of $10 \%, 5 \%$, and $1 \%$, respectively. Source: Author's calculations.

\section{ADDRESSING THE SELECTION AND REVERSE CAUSALITY ISSUES}

The relation between gender diversity and firm performance presented in section $V$ represents an association rather than a causality between them. In this section, we use two-stage regressions to examine whether there are any causalities between them. In the first-stage regressions, we examine the determinants of gender diversity and in the second-stage regressions, we examine whether the 
actual gender diversity change, with the predicted gender diversity controlled, impacts firm performance. In both stages, the explanatory variables are lagged by 1 year relative to the dependent variables. In the first-stage analyses, we include both the firm-level and the country-level instruments that are related to gender diversity but not directly related to firm performance.

In Table 4, we present the results of the two-stage analyses using data from the 10 countries. The first three columns address the causality between financial performance and having at least one female on the board; the next three, the appointment of a new female director; and the last three, female representation on the board. Panel A presents the results on the determinants of gender diversity and Panel B presents the impacts on firm performance.

As Panel A of Table 4 shows, none of the past performance measurements have any significant explanatory power on any measurement of firms' boardroom gender diversity. The autocorrelation of female ratio in the boardroom is 0.81 , which is consistent with the low turnover rate of board directors in practice. For each $1 \%$ increase in the female ratio in the past year, the likelihood that there is still at least one female on the board this year increases by $35 \%$.

Moreover, the instruments we choose significantly explain the gender diversity in cross section. The standard errors for these country-level instruments are clustered at the country level. As a supply measurement, gender equality in college education is significantly and positively associated with boardroom gender diversity, although female labor participation shows a surprisingly negative effect. One possible reason is that the available labor participation data include statistics for female workers at all levels. Women who take leadership positions constitute only a small portion of the total. While wage equality is an endogenous variable in labor market dynamics, the negative coefficient implies that the demand-side effect is stronger than the supply-side effect. Finally, as expected, infant survival equality has a negative and significant relation to boardroom gender diversity.

Panel B of Table 4 shows that the predicted gender diversity (estimated from the first-stage determinants analysis) predicts positive future firm performance. However, the actual gender diversity, which includes the unexpected shock in diversity, has no predictive power on future firm performance.

Table 5 presents the results from the two-stage analyses with the Singapore 7-year panel data. The empirical findings are similar to the data from the 10-country analyses. Note that, as a onecountry sample, we have only the firm-level instrument in the first stage.

Overall, these two-stage analyses deliver the following messages. First, past performance does not explain gender diversity-the reverse causality argument is not true. Firms do not necessarily increase female representation when performing well. Second, firms' existing female representation and female leadership supply and demand are the main determinants of firms' addition of female directors. Third, the association between gender diversity and firm performance, documented in section $\mathrm{V}$, is predictable using past information. There is no predictive power on firm performance when gender diversity deviates from the predicted level.

As the most important past information is the firm's boardroom gender diversity and gender equality in the premarket conditions, the value associated with gender diversity is therefore valid. Our evidence does not reject Becker's discrimination theory, as higher gender diversity is associated with better corporate performance. The relation, however, indeed differs across the performance measurements. 
Table 4: Gender Diversity and Firm Performance: Two-Stage Analyses with the 10-Country 4-Year Panel Data

\begin{tabular}{|c|c|c|c|c|c|c|c|c|c|}
\hline \multicolumn{10}{|c|}{ Stage 1: Predict Gender Diversity } \\
\hline & \multicolumn{3}{|c|}{ At Least One Female on the Board } & \multicolumn{3}{|c|}{ Appointment of Female Directors } & \multicolumn{3}{|c|}{ Female Directors on Board (ratio, \%) } \\
\hline Lagged ROA (\%) & $\begin{array}{r}1.69 \\
{[0.66]}\end{array}$ & & & $\begin{array}{r}0.02 \\
{[1.04]}\end{array}$ & & & $\begin{array}{r}0.04 \\
{[1.10]}\end{array}$ & & \\
\hline Lagged ROE (\%) & & $\begin{array}{r}-0.16 \\
{[-1.10]}\end{array}$ & & & $\begin{array}{r}-0.02 \\
{[-0.08]}\end{array}$ & & & $\begin{array}{r}-0.00 \\
{[-0.37]}\end{array}$ & \\
\hline Lagged stock market returns (\%) & & & $\begin{array}{r}-0.18 \\
{[-0.49]}\end{array}$ & & & $\begin{array}{r}0.01^{*} \\
{[1.80]}\end{array}$ & & & $\begin{array}{r}0.01 \\
{[1.07]}\end{array}$ \\
\hline Lagged female ratio (\%) & $\begin{array}{r}0.35^{* * *} \\
{[6.32]}\end{array}$ & $\begin{array}{r}0.35^{* * *} \\
{[6.35]}\end{array}$ & $\begin{array}{r}0.35^{* * *} \\
{[6.23]}\end{array}$ & $\begin{array}{r}-0.14 \\
{[-1.06]}\end{array}$ & $\begin{array}{r}-0.01 \\
{[-0.98]}\end{array}$ & $\begin{array}{r}-0.01 \\
{[-0.83]}\end{array}$ & $\begin{array}{r}0.81^{* * *} \\
{[20.80]}\end{array}$ & $\begin{array}{l}0.82^{* * *} \\
{[20.77]}\end{array}$ & $\begin{array}{l}0.81^{* * *} \\
{[18.86]}\end{array}$ \\
\hline College entry (female/male, \%) & $\begin{array}{l}0.03^{* *} \\
{[2.16]}\end{array}$ & $\begin{array}{l}0.03^{* *} \\
{[2.28]}\end{array}$ & $\begin{array}{c}0.03^{* *} \\
{[2.15]}\end{array}$ & $\begin{array}{l}0.03^{* *} \\
{[2.18]}\end{array}$ & $\begin{array}{l}0.03^{* *} \\
{[2.06]}\end{array}$ & $\begin{array}{r}0.03^{* * *} \\
{[2.82]}\end{array}$ & $\begin{array}{r}0.08^{* * *} \\
{[4.88]}\end{array}$ & $\begin{array}{r}0.08^{* * *} \\
{[4.65]}\end{array}$ & $\begin{array}{l}0.08^{* * *} \\
{[4.80]}\end{array}$ \\
\hline Female labor participation (\%) & $\begin{array}{r}-0.03 \\
{[-1.53]}\end{array}$ & $\begin{array}{r}-0.03 \\
{[-1.59]}\end{array}$ & $\begin{array}{r}-0.03 \\
{[-1.64]}\end{array}$ & $\begin{array}{r}-0.03 \\
{[-1.10]}\end{array}$ & $\begin{array}{l}-0.03 \\
{[-1.13]}\end{array}$ & $\begin{array}{l}-0.03 \\
{[-1.15]}\end{array}$ & $\begin{array}{c}-0.07^{* *} \\
{[-1.96]}\end{array}$ & $\begin{array}{l}-0.07^{* *} \\
{[-2.06]}\end{array}$ & $\begin{array}{c}-0.07^{* *} \\
{[-1.98]}\end{array}$ \\
\hline Wage equality (female/male, \%) & $\begin{array}{r}-0.01 \\
{[-0.06]}\end{array}$ & $\begin{array}{r}-0.01 \\
{[-0.01]}\end{array}$ & $\begin{array}{r}-0.07 \\
{[-0.03]}\end{array}$ & $\begin{array}{r}-0.01 \\
{[-0.16]}\end{array}$ & $\begin{array}{r}-0.08 \\
{[-0.17]}\end{array}$ & $\begin{array}{r}-0.01 \\
{[-0.30]}\end{array}$ & $\begin{array}{r}-0.07^{* * *} \\
{[-2.33]}\end{array}$ & $\begin{array}{r}-0.08^{* * * *} \\
{[-2.31]}\end{array}$ & $\begin{array}{r}-0.09^{* * *} \\
{[-3.14]}\end{array}$ \\
\hline Infant survival (girl/boy, \%) & $\begin{array}{c}-0.14^{*} \\
{[-1.85]}\end{array}$ & $\begin{array}{l}-0.14^{* *} \\
{[-2.04]}\end{array}$ & $\begin{array}{r}-0.14^{*} \\
{[-1.97]}\end{array}$ & $\begin{array}{r}-0.09 \\
{[-0.80]}\end{array}$ & $\begin{array}{r}-0.09 \\
{[-0.85]}\end{array}$ & $\begin{array}{r}-0.09 \\
{[-0.87]}\end{array}$ & $\begin{array}{r}0.06 \\
{[0.27]}\end{array}$ & $\begin{array}{r}0.05 \\
{[0.21]}\end{array}$ & $\begin{array}{r}0.06 \\
{[0.27]}\end{array}$ \\
\hline Firm characteristics & Yes & Yes & Yes & Yes & Yes & Yes & Yes & Yes & Yes \\
\hline Industry fixed effect & Yes & Yes & Yes & Yes & Yes & Yes & Yes & Yes & Yes \\
\hline Number of observations & 625 & 624 & 583 & 625 & 624 & 583 & 625 & 624 & 583 \\
\hline R-squares & 0.55 & 0.55 & 0.56 & 0.05 & 0.05 & 0.06 & 0.70 & 0.70 & 0.70 \\
\hline \multicolumn{10}{|c|}{ Stage 2: Performance Effect with Predicted Gender Diversity Controlled } \\
\hline & $\mathrm{ROA}(\%)$ & ROE $(\%)$ & $\begin{array}{c}\text { Stock Market } \\
\text { Returns (\%) }\end{array}$ & $\mathrm{ROA}(\%)$ & ROE (\%) & $\begin{array}{c}\text { Stock Market } \\
\text { Returns (\%) }\end{array}$ & ROA (\%) & ROE (\%) & $\begin{array}{c}\text { Stock Market } \\
\text { Returns (\%) }\end{array}$ \\
\hline At least one female on the board & $\begin{array}{r}1.15 \\
{[1.17]}\end{array}$ & $\begin{array}{r}4.55 \\
{[1.45]}\end{array}$ & $\begin{array}{r}-0.15 \\
{[-0.04]}\end{array}$ & & & & & & \\
\hline Appointment of female directors & & & & $\begin{array}{r}1.18 \\
{[1.06]}\end{array}$ & $\begin{array}{r}3.64 \\
{[0.94]}\end{array}$ & $\begin{array}{l}-4.40 \\
{[-1.11]}\end{array}$ & & & \\
\hline Female directors on board (\%) & & & & & & & $\begin{array}{r}0.06 \\
{[0.95]}\end{array}$ & $\begin{array}{r}0.20 \\
{[1.15]}\end{array}$ & $\begin{array}{r}-0.23 \\
{[-1.09]}\end{array}$ \\
\hline Predicted likelihood/ratio & $\begin{array}{r}-0.11 \\
{[-0.77]}\end{array}$ & $\begin{array}{l}-0.88^{*} \\
{[-1.81]}\end{array}$ & $\begin{array}{l}1.02^{*} \\
{[1.75]}\end{array}$ & $\begin{array}{l}5.13^{* * *} \\
{[3.60]}\end{array}$ & $\begin{array}{r}-4.45 \\
{[-0.79]}\end{array}$ & $\begin{array}{r}16.71^{* * *} \\
{[4.64]}\end{array}$ & $\begin{array}{l}-0.07 \\
-.96]\end{array}$ & $\begin{array}{r}0.04^{*} \\
{[-1.76]}\end{array}$ & $\begin{array}{r}0.53^{*} \\
{[1.92]}\end{array}$ \\
\hline Firm characteristics & Yes & Yes & Yes & Yes & Yes & Yes & Yes & Yes & Yes \\
\hline Industry fixed effect & Yes & Yes & Yes & Yes & Yes & Yes & Yes & Yes & Yes \\
\hline Number of observations & 597 & 594 & 566 & 597 & 597 & 566 & 597 & 597 & 566 \\
\hline R-squares & 0.07 & 0.10 & 0.08 & 0.10 & 0.09 & 0.09 & 0.07 & 0.10 & 0.07 \\
\hline
\end{tabular}

$\mathrm{ROA}=$ return on assets, $\mathrm{ROE}$ = return on equity.

Note: Figures in brackets are the t-statistics of the coefficient estimates; ${ }^{*}, * *$ and ${ }^{* * *}$ denote significance of $10 \%, 5 \%$, and $1 \%$, respectively.

Source: Author's calculations. 
Table 5: Gender Diversity and Firm Performance: Two-Stage Analyses with the 7-Year Panel Data from Singapore

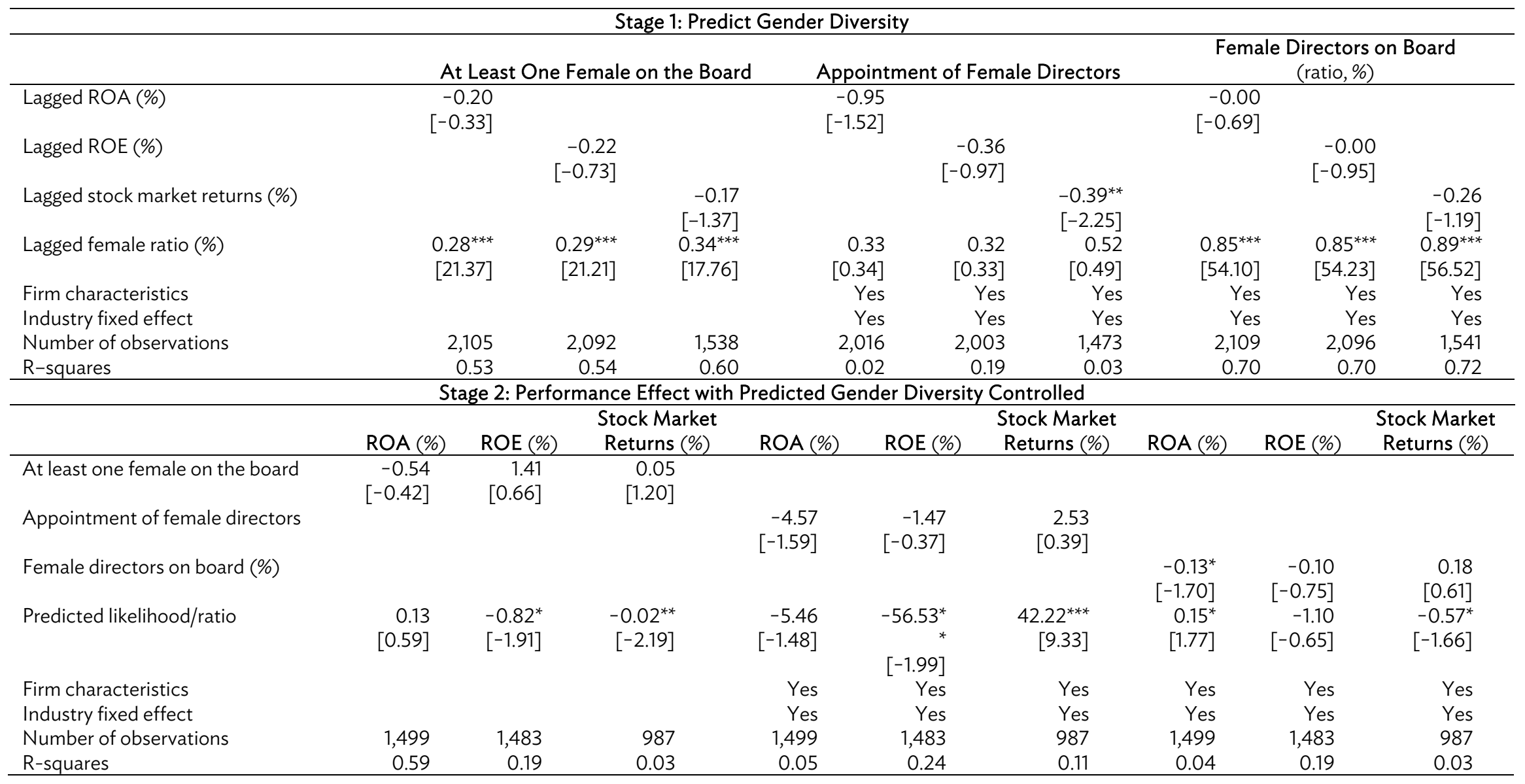

$\mathrm{ROA}=$ return on assets, $\mathrm{ROE}=$ return on equity.

Notes: Figures in brackets are the $t$-statistics of the coefficient estimates; ${ }^{*},{ }^{* *}$, and ${ }^{* *}$ denote significance of $10 \%, 5 \%$, and $1 \%$, respectively.

Source: Author's calculations. 


\section{CONCLUSIONS}

This paper reviews the concept, theory, and international evidence on gender diversity and its relation to financial performance. We examine gender diversity in corporate leadership in 10 economies in Asia and the Pacific and find that gender diversity is overall lower in this region compared with North America and Europe. Among the 10 economies studied, Australia has the highest female ratio in corporate leadership and the Republic of Korea, the lowest. India and Malaysia are the only countries that currently have mandatory gender diversity quotas for the senior management positions or boards. The implementation is however poor in India. The PRC potentially loses economic value by the largest magnitude because of the lack of gender diversity.

On the relation between gender diversity and firms' financial performance, we find that firm performance is the highest when there are two females on the board. The boardroom female representation and appointing new female directors are positively associated with the firm performance in the subsequent year. Consistent with the existing international empirical evidence, we also find that the relation between gender diversity and financial performance display large crosscountry and cross-measurement differences.

In the two-stage analyses to address the endogenous concerns on gender diversity determinants, we find the following. First, firms' past performance does not predict corporations' female director choices. That is, the reverse causality argument of financial performance to gender diversity is not true. Second, the economic demand and supply of female leadership measured by gender equality in college education, labor participation, wages, and infant survival significantly explain the cross-country differences in female corporate leadership. Third, female representation on the board, when determined by the economic factors, predicts significant and mostly positive firm future performance. There are, however, still cross-measurement differences. Finally, changes in gender diversity that are unrelated to the economic factors have no predictive power on firm performance.

Our findings generate clear and strong recommendations for government policies on gender diversity in corporate leadership. On the one hand, arbitrary quotas of female representation in leadership without economic justification may produce little in terms of financial performance. On the other hand, government policies that aim to improve female leadership through improving the gender equality in society will be well rewarded in capitalizing on human talents. 


\section{REFERENCES}

Adams, R., and D. Ferreira. 2009. Women in the Boardroom and Their Impact on Governance and Performance. Journal of Financial Economics. 94 (2). pp. 291-309.

Adams, R., and P. Funk. 2012. Beyond the Glass Ceiling: Does Gender Matter? Management Science. 58 (2). pp. 219-35.

Adams, R, S. Gray, and J. Nowland. 2011. Does Gender Matter in the Boardroom? Evidence from the Market Reaction to Mandatory New Director Announcements.

Adams, R. B., and T. Kirchmaier. 2013. Making It to the Top: From Female Labor Force Participation to Boardroom Gender Diversity. ECGI-Finance Working Paper 347.

Adams, R., and V. Ragunathan. 2014. Lehman Sisters. Financial Research Network (FIRN) Research Paper.

Albrecht, J., A. Björklund, and S. Vroman. 2003. Is There a Glass Ceiling in Sweden? Journal of Labor Economics. 21 (1). pp. 145-77.

Ahern, K., and A. Dittmar. 2012. The Changing of the Boards: The Impact on Firm Valuation of Mandated Female Board Representation. Quarterly Journal of Economics. 127 (1). pp. 137-97.

Amin, M., and A. Islam. 2015. Women Managers and the Gender-Based Gap in Access to Education Evidence from Firm-Level Data in Developing Countries. World Bank Policy Research Working Paper Series. No. 726.

Angier, M., and B. Axelrod. 2014. Realizing the Power of Talented Women. McKinsey Quarterly. September.

Apesteguia, J., G. Azmat, and N. Iriberri. 2012. The Impact of Gender Composition on Team Performance and Decision Making: Evidence from the Field. Management Science. 58 (1). pp. 78-93.

Barsh, J. 2014. Can Women Fix Capitalism? McKinsey Quarterly. September.

Beaman, L., E. Duflo, R. Pande, and P. Topalova. 2012. Female Leadership Raises Aspirations and Educational Attainment for Girls: A Policy Experiment in India. Science. 335 (6068). pp. 58286.

Bernard, T. S. 2014. Vigilant Eye on Gender Pay Gap. New York Times. 14 November.

Bertrand, M., S. Black, S. Jensen, and A. Lleras-Muney. 2015. Breaking the Glass Ceiling? The Effect of Board Quotas on Female Labor Market Outcomes in Norway. NBER Working Paper Series No. 20256. Cambridge, MA: National Bureau of Economic Research.

Bertrand, M., C. Goldin, and L. Katz. 2010. Dynamics of the Gender Gap for Young Professionals in the Financial and Corporate Sectors. American Economic Journal: Applied Economics. 2 (3). pp. 22855. 
Campbell, K., and A. Minguez Vera. 2010. Female Board Appointments and Firm Valuation: Short and Long-Term Effects. Journal of Management and Governance. 14 (1). pp. 37-59.

Carter, D., B. Simkins, and W. G. Simpson. 2003. Corporate Governance, Board Diversity, and Firm Value. Financial Review. 38 (1). pp. 33-53.

Croson, R., and U. Gneezy. 2009. Gender Differences in Preferences. Journal of Economic Literature. 47 (2). pp. 448-74.

Dieleman, M., M. Qian, and M. Ibrahim. 2013. Singapore Board Diversity Report 2013-Time for Women to Rise. Centre for Governance, Institutions and Organisations.

- 2014. Singapore Board Diversity Report 2014-Picture the Performance Premium. Centre for Governance, Institutions and Organisations.

Doldor, E., S. Vinnicombe, M. Gaughan, and R. Sealy. 2012. Gender Diversity on Boards: The Appointment Process and the Role of Executive Search Firms. Equality and Human Rights Commission Research Report Series No. 85.

Eckel, C., and P. Grossman. 2008. Men, Women and Risk Aversion: Experimental Evidence. Handbook of Experimental Economics Results. Volume 1. pp. 1061-73.

Erhardt, N., J. Werbel, and C. Shrader. 2003. Board of Director Diversity and Firm Financial Performance. Corporate Governance: An International Review. 11 (2). pp. 102-11.

Farrell, K., and P. Hersch. 2005. Additions to Corporate Boards: The Effect of Gender. Journal of Corporate Finance. Volume 11. pp. 85-106.

Fitch, K., and S. Agrawal. 2015. Female Bosses Are More Engaging Than Male Bosses. Business Journal. 7 May.

Gneezy, U., M. Niederle, and A. Rustichini. 2003. Performance in Competitive Environments: Gender Differences. The Quarterly Journal of Economics. 118 (3). pp. 1049-74.

Grant Thornton International. 2014. Women in Business: From Classroom to Boardroom, Grant Thornton International Business Report 2014.

- 2015. Women in Business: The Path to Leadership. Grant Thornton International Business Report 2015.

Hogarth, R., N. Karelaia, and C. A. Trujillo. 2012. When Should I Quit? Gender Differences in Exiting Competitions. Journal of Economic Behavior \& Organization. 83 (1). pp. 136-50.

Huang, J., and D. Kisgen. 2013. Gender and Corporate Finance: Are Male Executives Overconfident Relative to Female Executives? Journal of Financial Economics. 108 (3). pp. 822-39.

Korn Ferry Institute. 2012. The Diversity Scorecard Measuring Board Composition in Asia Pacific. Korn Ferry International. 
Levi, M., K. Li, and F. Zhang. 2014. Director Gender and Mergers and Acquisitions. Journal of Corporate Finance. 28. pp. 185-200.

Lukas, C. 2014. Boardroom Quotas Won't Help Women. The New York Times. 7 December.

Lyness, K., and M. Judiesch. 1999. Are Women More Likely to Be Hired or Promoted into Management Positions? Journal of Vocational Behavior. 54 (1). pp. 158-73.

Matsa, D., and A. Miller. 2011. Chipping Away at the Glass Ceiling: Gender Spillovers in Corporate Leadership American Economic Review P\&P. 101 (2). pp. 635-39.

- 2013. A Female Style in Corporate Leadership? Evidence from Quotas. American Economic Journal: Applied Economics. 5 (3). pp. 136-69.

Sapienza, P., L. Zingales, and D. Maestripieri. 2009. Gender Differences in Financial Risk Aversion and Career Choices Are Affected by Testosterone. Proceedings of the National Academy of Sciences. 106 (36). pp. 15268-73.

Srinidhi, B., F. Gul, and J. Tsui. 2011. Female Directors and Earnings Quality. Contemporary Accounting Research. 28 (5). pp. 1610-44.

Tuminez, A., and M. del Mar Garza, eds. 2014. Women Leaders and the New Asian Century: Insights from the Government, Private Sector, and Civil Society. National University of Singapore.

Westphal, J., and E. Zajac. 1995. Who Shall Govern? CEO/Board Power, Demographic Similarity, and New Director Selection. Administrative Science Quarterly. 40 (1). pp. 60-83.

World Bank. Gender Equality Data and Statistics. http://data.worldbank.org/topic/gender 


\section{Women's Leadership and Corporate Performance}

Is leadership diversified in Asian corporate boardrooms? How is gender diversity in corporate leadership associated with financial performance? What is the magnitude of potential gain by allocating human talents more efficiently without gender bias? What kind of policy might be useful to improve the gender diversity in corporate leadership? These questions are intriguing and relevant. This paper provides insights into these questions through theoretical review and empirical analyses.

\section{About the Asian Development Bank}

ADB's vision is an Asia and Pacific region free of poverty. Its mission is to help its developing member countries reduce poverty and improve the quality of life of their people. Despite the region's many successes, it remains home to the majority of the world's poor. ADB is committed to reducing poverty through inclusive economic growth, environmentally sustainable growth, and regional integration.

Based in Manila, ADB is owned by 67 members, including 48 from the region. Its main instruments for helping its developing member countries are policy dialogue, loans, equity investments, guarantees, grants, and technical assistance.

$\mathrm{ADB}$ 